\title{
Facial skin cancers: general information and an overview of treatment methods
}

\author{
Henryk Witmanowski ${ }^{1,2}$, Edward Lewandowicz ${ }^{3}$, Daria Sobieszek³, Jan Rykała ${ }^{3}$, Magdalena Łuczkowska $^{4}$ \\ 1Department of Plastic, Reconstructive and Aesthetic Surgery, Collegium Medicum in Bydgoszcz, Nicolaus Copernicus University \\ in Torun, Poland \\ Head: Prof. Henryk Witmanowski MD, PhD \\ 2Department of Physiology, Poznan University of Medical Sciences, Poland \\ Head: Prof. Teresa Torlińska MD, PhD \\ ${ }^{3}$ Department of Plastic, Reconstructive and Aesthetic Surgery, Medical University of Lodz, Poland \\ Head: Prof. Bogusław Antoszewski MD, PhD \\ ${ }^{4}$ Department of Dermatology, Poznan University of Medical Science, Poland
}

Head: Prof. Wojciech Silny MD, PhD

Postep Derm Alergol 2012; XXIX, 4: 240-255

DOI: 10.5114/pdia.2012.30462

\begin{abstract}
Introduction: Malignant tumors of the skin are the most common human cancers. Among them facial skin cancers form a sizable group. In recent years there has been a dynamic increase in morbidity. They are characterized by local invasiveness, they infiltrate the surrounding tissues, destroy adjacent structures and lead to significant loss of tissue, which represent a serious therapeutic problem as they are reported in advanced stages of development, and after surgery there are extensive losses of disrupting the aesthetics and function of the face. The most common tumor is basal-cell carcinoma (BCC), another is squamous cell carcinoma (SCC). In available bibliography there is no clear information about the standards of treatment of this type of cancer is observed, which led us to try to present basic information about facial skin cancers, their morphological and histological forms, and the routine treatment depending on location.

Aim: The paper presents the current knowledge on non-melanoma cancers of the face, the algorithm according to the primary lesion location and the related therapeutic options. It also presents the possibility of reconstruction of tissue defects, depending on the location of the change on the basis of selected patients treated at the Department of Plastic, Reconstructive and Aesthetic Surgery, Medical University of Lodz.

Material and methods: In the Clinic of Plastic, Reconstructive and Aesthetic Surgery, Medical University of Lodz in the years 1998-2008, 398 patients were treated because of non-melanoma skin cancers.

Results: The method of surgical treatment depended on the type of cancer, its stage and location. In the case of changes located on the face, in the advancement of T1 (T1NOMO), a surgical excision with local plastics was introduced, in other cases - local flaps or skin grafts was applied.

Conclusions: Despite enormous progress in medical science, surgery remains the method of choice in treating facial cancers. Only the primary cut and the suitable technique of plastic surgery, selected individually for each patient provides satisfactory results.
\end{abstract}

Key words: non-melanoma cancers of the face, treatment, reconstruction, facial skin cancers.

\section{Introduction}

\section{General information}

In 1998-2008, the Clinic of Plastic and Reconstructive Surgery, Medical University of Lodz, treated 398 patients with cancers located on the face. They are the most common malignancy occurring in humans [1] and a third of all cancers detected. The incidence rate is difficult to determine because of the lack of precise registration. In recent years there has been a rise in incidence in the U.S. by $10-15 \%$ annually. It is more likely in males (2: 1$)$. Incidence rate is $1.7 \%$ /year in the world [2] and in the Asian population [3]. In studies of Andrade 52.4\% of non-melanoma cancers were found in women [4]. The most common 
of these is the basal-cell carcinoma (BCC) [5] and it is often not included in the registers, which causes skin cancers to occupy distant positions in them. The second most common cancer is squamous cell carcinoma (BCC/SCC = 3 : 1) [6]. In Poland they cause about 1500 deaths every year [7]. The diagnosis is based on the histopathological examination.

\section{Factors predisposing}

An increased incidence of non-melanoma skin cancers is observed in males with fair skin, poor tanning ability, blond hair, blue eyes, and depends on the age and time of exposure to sunlight. he development of skin cancer predisposition:

- UV radiation - blocks of DNA repair mechanisms, mutations in the p53 gene have been shown in over $90 \%$ of SCC and more than $50 \%$ of BCC [8]; UVB rays are particularly dangerous, and the time of exposure is of crucial importance [9];

- skin phototype (I-VI) and the related amount of melanin - the more the greater the protection, these are cancers of the white race;

- ionizing radiation - showed an increase in the incidence of BCC and SCC in radiologists and in patients with actinic dermatitis [10];

- immunosuppression - both drugs, transplants or by the action of UV radiation on the immune system (reducing the number of Langerhans cells, suppression of cellular response) [11]; in conditions associated with immunosuppression such as AIDS, an increase in the incidence of skin cancers is observed [12];

- chronic wounds and scars after burn - SCC is more likely to develop in them [13];

- chemicals - creosote, formaldehyde and others - particularly predispose to SCC [14];

- precancerous lesions of the skin, which include:

- actinic keratosis - 16\% pass in the SCC [15],

- pigmented skin and xeroderma pigmentosum a genetic disorder that affects repairing DNA damage, which occurs under the influence of UV radiation; the greatest damage occurs under the influence of UVB [16],

- keratoacanthoma [17] - described in 1889, by Hutchinson's tumor arising in areas exposed to sunlight, characterized by rapid growth (4-8 weeks), may underlie malignant cases,

- seborrhoeic wart, dermatofibroma (no precancerous lesions) [18],

- Bowen's disease - 3-11\% after years become invasive SCC, the preferred treatment is 5-FU and excision $[19,20]$. According to the work of Graham et al., Bowen's disease increases the incidence of cancer of internal organs [20],

- leukoplakia - if the SCC develops on leukoplakia, the risk of metastasis is greater than in the case of actinic keratosis [21],
- Marjolin's ulcer [22],

- Bowenoid pustulosis,

- Queyrat's disease [21];

- Jadassohn's stigma - congenital lesion of the scalp.

Predisposing syndromes:

- Gorlin syndrome (a genetic mutation in the gene locus 9q22.3 PTCH2.), it is inherited as an autosomal dominant trait, in the form of multiple signs and is often accompanied by developmental defects and cysts of the jaw, rib defects $[23,24]$,

- Bazex syndrome - (BCC, hypotrichosis, hypohidrosis) and its variant Rombo syndrome $[25,26]$.

In the WHO classification of tumors, BCC and SCC are included in a group of squamous cell tumors originating from the basal layer (BCC) or spinal (SCC) of the epidermis.

\section{Basal cell carcinoma}

Basal cell carcinoma (carcinoma basocellulare, basalioma, ulcus rodens, BCC) is the most common cancer characterized by a low degree of malignancy, slow growth and a very rare formation of metastases to regional lymph nodes (lymphatic route, 0.003-0.1\%) by high degrees of proficiency. It comes from the basal cell layer of the epidermis. According to the Skin Cancer Foundation, in the U.S. each year about 800,000 people get the disease. The BCC develops in the skin not previously modified or from precancerous lesions. Incidence increases with age. About $85 \%$ of BCC cases are localized in the head and neck, usually in the nose (> 25\%), orbit (7\%) or the external ear (6\%) and lips, usually above the palate line [7, 27].

Risk factors include age, male gender, type I and II of the skin, used immunosuppressive drugs, high-fat diet. BCC also fosters the development of the earlier outbreak of BCC in a different place [28].

Factors influencing the prognosis are: tumor size (the bigger the greater the chance of recurrence), location (central part of the face (around the eyes, nose, lips) and around the ears - a high-risk BCC), the borders of change (ill-defined increase of the risk of recurrence), histological type, histological type of aggression (perineural, perivascular - increase the risk of recurrence), reoperation, used immunosuppression.

Surgical excision of primary BCC gives recurrence observed in 5 years in only about $2 \%$. For small changes $(<20 \mathrm{~mm})$, excision with a margin of $3 \mathrm{~mm}$ gives a cure rate of $85 \%$, widening the margin to $4-5 \mathrm{~mm}$ increases the proportion of cured cases to $95 \%$. In the case of a morpheaform cut with a margin of $3 \mathrm{~mm}$ gives a cure only in $66 \%$, so in this form it is suggested to apply a wider margin. Incomplete excision is observed in approximately 4-7\% (studies in the GB and Australia). Despite incomplete excision, recurrence within 2-5 years observed in an independent research is only 30-41\%. Trimming of incompletely excised BCC demonstrates the presence of malignant cells in only $45-54 \%$ of specimens in two independent histopathological studies. The decisive factor seems to be a deep cut margin [28-30]. 
Morphological variations are defined as follows:

1. Deep

- nodular (carcinoma basocellulare nodosum) the most common form of BCC, $21 \%$; nodule surrounded by characteristic non-inflammatory pearly shaft. In the central part of a nodule there may be scarring, initial size of a pinhead, pink-red focus, growing quickly. Within the nodule there may be present multiple telangiectasia and scaling, bleeds easily,

- ulcerative (carcinoma basocellulare exulcerans, historical name: penetrating ulcer - ulcus rodens) form is characterized by deep infiltration of the tumor base, which could lead to destruction of the muscle and bone. A characteristic clinical BCC nodule surrounding the shaft may be in the form that is barely perceptible. It arises from a nodular variety, which under the influence of perfusion abnormalities is necrotic in the middle, with a slightly infiltrated bottom and slightly haughty, hardened edges of the pearl type, bleeds easily, has the ability to infiltrate the stroma,

- pigmentosa (carcinoma basocellulare pigmentosum),

- scleroderma (carcinoma basocellulare morpheiforme) - is a porcelain colored nodule, usually not liable to decay, focus close to the limited scleroderma, whitish, with increased cohesiveness, haughty, but slightly reduced edges, the periphery can be in the form of a pearly hill,

- cystic (carcinoma basocellulare cysticum) - localized usually on the eyelids as small, translucent nodules,

- scarring (BCC planum cicatricans): scar surrounded by a pearly shaft.

2. Superficial = crawling (basocellulare superficial carcinoma) - a form of mild and chronic course, in which superficial lesions are generally numerous, well marked out, and spread very slow. Only a shaft with a single change is present. No major breakdown or appearance of scar formation; it is difficult to establish the diagnosis early. The most common location of this form of cancer is the trunk, a variation of a surface is called Arning's tumor (carcinoma basocellulare superficial multicentricum). All varieties of BCC are characterized by a slow process and the typical location is the face, they never harm the eye and do not take up the mucous membranes, except as an ulcerative form, infiltrating stroma only slightly. Five-year survival without metastases is given in more than $90 \%$, the local recurrence rate is close to $50 \%$ [21].

Histological types are as follows: undifferentiated carcinoma (solidum), cystic (cysticum), glandular (adenoides), keratoticum and pigmentosum.

\section{Squamous cell carcinoma}

The second most common SCC arises from the squamous layer of the skin's corneum and mucous membranes. The SCC has higher virulence (grading I-IV depending on the number of differentiated cells), and morphologically no pearly shaft surrounding the change is observed.

Early squamous cell carcinoma of the skin (carcinoma in situ) is a sharply limited red erythema. Advanced lesions are nodular with hyperkeratosis (papillary) and sometimes ulcerative. Characteristic features include the infiltration base and embankment edge changes, absence of pearly, translucent aspect and much less telangiectasia.

It is usually located on the border of the mucosa and skin in the lower part of the face, below the line connecting the corner of the mouth and ear lobe.

It is characterized by a relatively rapid growth and tendency to metastasize (3-5\%), rising to 30\% for the location on the border of the skin and mucous membranes, or local recurrence [31]. For diagnosis histological examination is necessary. Samples are collected through excisional biopsy, shear (biopsy), fragmented biopsy, or biopsy of lymph nodes.

There are two types of SCC:

- exophytic form (type I) characterized by the occurrence of ulcers and late metastasis,

- endophytic form (type II) growing faster than ulcerative, metastasizing faster to lymph nodes (85\%) or distant (15\%) [21].

The SCC grade of differentiation also depends on the individual cell structures and the tendency to keratinization. To evaluate the four-grade scale of Broders is used (undifferentiated cells to evaluate the amount of the entire tumor mass) [32].

\section{Aim}

The paper presents the fundamental histopathological differences between the carcinomas of the face, the algorithm of treatment according to the primary lesion and the related therapeutic options. It also presents the possibility of reconstruction of facial defects, depending on the location of the change on the basis of selected patients treated at the Department of Plastic, Reconstructive and Aesthetic Surgery, Medical University of Lodz.

\section{Material and methods}

In the Clinic of Plastic, Reconstructive and Aesthetic Surgery, Medical University of Lodz in 1998-2008, 398 patients were treated. The method of surgical treatment depended on the type of cancer, its stage and location. For the changes located on the face, in the advancement of $\mathrm{T} 1 \mathrm{a}$ simple excision and repair, in other cases, flaps or skin grafts were used. 
Table 1. Risk factors for recurrent non-melanoma skin cancers - author's modification [33]

\begin{tabular}{|c|c|c|}
\hline Factors & Low risk of recurrence & High risk of recurrence \\
\hline \multicolumn{3}{|l|}{ Clinical } \\
\hline \multirow[t]{3}{*}{ Size } & - The area of "low risk" (trunk, limbs) < $20 \mathrm{~mm}$ & $>20 \mathrm{~mm}$ \\
\hline & $\begin{array}{l}\text { - The area of "medium risk" (cheeks, forehead, } \\
\text { neck, scalp < } 10 \mathrm{~mm}\end{array}$ & $>10 \mathrm{~mm}$ \\
\hline & $\begin{array}{l}\text { - The area of "high risk" (the center of the face, } \\
\text { eyelids, eyebrows, nose, lips, cheeks, chin, ears) }<6 \mathrm{~mm}\end{array}$ & $>6 \mathrm{~mm}$ \\
\hline Borders & Well defined & Poorly defined \\
\hline Immunosuppression & Negative & Positive \\
\hline Radiotherapy & - & + \\
\hline Chronic inflammation (SCC) & - & + \\
\hline Rapid growth (SCC) & - & + \\
\hline Neurological symptoms (SCC) & - & + \\
\hline \multicolumn{3}{|l|}{ Pathological } \\
\hline Subtype (BCC) & Nodular, superficial & Other types \\
\hline Differentiation (SCC) & Well differentiated & Poorly differentiated \\
\hline Infiltration into SCC (Clark) & I, II, III or $<4 \mathrm{~mm}$ & $\mathrm{IV}, \mathrm{V}$ or $>4 \mathrm{~mm}$ \\
\hline Subtype (SCC) & Other types & Adenoid, adenosquamous \\
\hline
\end{tabular}

\section{Methods of treatment}

Surgical treatment: the method of choice in the treatment of skin cancer is excision with a margin of healthy tissue [34-37]. The margin for BCC is about 5-10 mm, and for SCC - 10-15 $\mathrm{mm}$. The type of the surgical procedure depends on the character, stage and location of the tumor, the general condition of the patient and the result of histopathological examination. In the case of BCC, it is sufficient to remove the primary lesion, in the case of SCC $>2 \mathrm{~cm}$ lymph nodes should also be removed (according to some authors, as standard, according to others, only in more advanced cases). Undoubted benefits of surgical treatment is the high curability rate reaching $98 \%$ for $\mathrm{BCC}$, good cosmetic results, short duration of treatment, the possibility of performing a histopathological examination.

Other treatment methods include:

- curettage and electrocoagulation ( $C$ and D curettage and electrodessication) - sometimes used for small $(<1 \mathrm{~cm})$ primary changes [38];

- Mohs micrographic surgery - microscopically controlled surgery. Full histopathological control of edges of the removed changes, ensuring completeness of excision with a minimal loss of healthy tissues, used especially in areas where it is important to avoid unnecessary loss of healthy tissue: the nose, eyelids, the area of the ear, lip; lower risk of recurrence $(<5 \%)[39,40]$;
- chemotherapy - 5\% ointment of 5-fluorouracyl for superficial BCC [41], bleomycin [42], interferon $\alpha-$ experimentally in BCC and SCC [43];

- radiation therapy (teleradiotherapy, brachytherapy) good cosmetic result, cancers of the central part of the face; defects - actinic dermatitis, should be avoided at the location on the eyelids, nose, ear, reserved for patients with contraindications to surgery [44, 45];

- cryosurgery - only for small, superficial BCC changes, for the other it is not recommended, freezing with liquid nitrogen or nitrous oxide [46, 47];

- photodynamic therapy - give intravenous or topical photosensitizing substance, which, after 24-48 h accumulates in tumor cells, then radiates with the wave length of 630-660 nm or a laser - by photo-oxidation chemical reaction occurs and leads to death of cancer cells. Low efficacy, relapse is characterized by higher histological malignancy [48].

Surgical treatment of non-melanoma skin facial tumors with local art, depending on the location.

1. The forehead and scalp

Forehead skin changes with age and depends on ethnic factors. The skin is usually smooth in youth, and covered with wrinkles in the elderly. Unfortunately, there is no disposal of excess skin. When planning the treatment we pay attention to the surrounding anatomic structures. Small defects are closed primarily in a transverse or sagit- 
Table 2. Comparison of advantages and disadvantages of treatment for non-melanoma skin cancers of the face - modified by the author [33]

\begin{tabular}{|c|c|c|c|}
\hline Method of treatment & Efficacy & Disadvantages & Advantages \\
\hline Surgery & $\begin{array}{l}\text { To } 98 \% \text { (primary lesion) } \\
\text { To } 80 \% \text { (recurrence) }\end{array}$ & $\begin{array}{l}\text { Scar, infection, possible post } \\
\text { operation complications }\end{array}$ & $\begin{array}{l}\text { Short time of treatment, a good cosmetic } \\
\text { result }\end{array}$ \\
\hline Mohs excision & To $99 \%$ (primary lesion) & $\begin{array}{l}\text { Large defects of the skin, } \\
\text { time-consuming, requires training } \\
\text { and special technique }\end{array}$ & Exact controlling of the edge of the defect \\
\hline Radiotherapy & $\begin{array}{l}95 \%(<5 \mathrm{~mm}) \\
85 \%(15 \mathrm{~mm})\end{array}$ & $\begin{array}{l}\text { Radiation injury, poor cosmetic } \\
\text { effect }\end{array}$ & Inoperable tumors, palliative procedures \\
\hline Chemotherapy & $\begin{array}{l}\text { Depends on the type } \\
\text { and size }\end{array}$ & Frequent recurrence & Toxicity, palliative procedures, prolongs life \\
\hline Cryosurgery & To $95 \%(<2 \mathrm{~cm})$ & $\begin{array}{l}\text { Scars, pigmentation disorders, } \\
\text { lack of histopathologic evaluation }\end{array}$ & $\begin{array}{l}\text { Quick and easy method, not effective } \\
\text { at relapse }\end{array}$ \\
\hline Photodynamic therapy & $10-40 \%$ & $\begin{array}{l}\text { Recommended for small } \\
\text { and superficial changes, } \\
\text { limited penetration of life, } \\
\text { lack of histopathologic evaluation }\end{array}$ & \\
\hline $5-\mathrm{FU}$ & Low & $\begin{array}{l}\text { Pigmentation disorders, } \\
\text { long-term treatment }\end{array}$ & Non invasive method \\
\hline $\begin{array}{l}\text { Curettage and } \\
\text { electrodessication }\end{array}$ & $\begin{array}{l}100 \%(<2 \mathrm{~mm}) \\
50 \%(>3 \mathrm{~cm})\end{array}$ & $\begin{array}{l}\text { Hypertrophic scars, pigmentation } \\
\text { disorders, lack of histopathologic } \\
\text { evaluation }\end{array}$ & Available and widely used method \\
\hline
\end{tabular}

tal direction. Large loss of tissue is covered with the pedicle flaps, often advancement or rotation flaps.

2. Cheek, upper and lower lip

Buccal cavities, if it is not possible to close primarily within aesthetic units, we close with flaps shifted from the neighborhood, before ear - or - retroauricular, nasolabial fold or glabella. It is possible to use rotation flaps from the neck, temporal or before ear area. Large defects can also be covered with full-thickness skin grafts taken from the retroauricular, supraclavicular or medial arm area.

Small defects of the lip are cut following certain principles: small cavities are cut horizontally, losses exceeding the vermilion border are cut with Z-plasty, in the case of a partial or total excision of the lip, reconstruction is performed by moving the mucous membrane of the mouth or tongue. Large defects of the upper lip can be covered using the Abbe's flap originating from the lower lip, flap rotation (fan flap) or perialar crescentic advancement flap. Small defects of the lower lip may be closed directly or with sliding lip tissue and closed in layers or closed using the method of Karapandzic. Defects in excess of $1 / 3$ of the lower lip require lip switching procedures (Gilles flap, McGregor flap, Estlander flap) or tubular flap (Figures 1-8).

3. Upper and lower eyelid

Small defects are cut and supplied with local tissue advancement. For the larger defects we can use free skin grafts (FTSG-full-thickness skin graft) taken from behind the ear or the opposing side of the eyelids. Extensive loss of the upper eyelid can be covered with flaps (Mustarde's flap, moved from the cheek, or Abbe's flap taken from the opposite lid). Sometimes there is a need to cover the defect with muco-cartilage graft from the nasal septum or cartilage of the auricle. Large defects of the lower lid are supplied using local flaps (Mustarde's flap, Frickie's flap or advancement flap from cheek). For the reconstruction of the upper and lower lid, flaps from the forehead can be used (Figures 9-16).

4. Nose

For the closure of defects after removal of nasal tumors various techniques of flaps can be used. In the case of location on the dorsum of the nose, flaps from glabella or forehead are preferred: advancement (Rintal, Schmidt), bilobed flaps, rotation-advancement flaps of residual dorsal skin. In the case of the lateral part of the nose, the preferred options are bilobed flaps, rotation or advancement moved from the neighborhood (Reinwald, McGregor) or from the nasolabial fold. For reconstruction of nostrils, a composed graft from auricle can be used. If more complex reconstruction is necessary (wings) we can use the whole middle part of the forehead, sometimes prepared before by the expander. In the case of total reconstruction of the nose, a flap from the forehead can be used or 

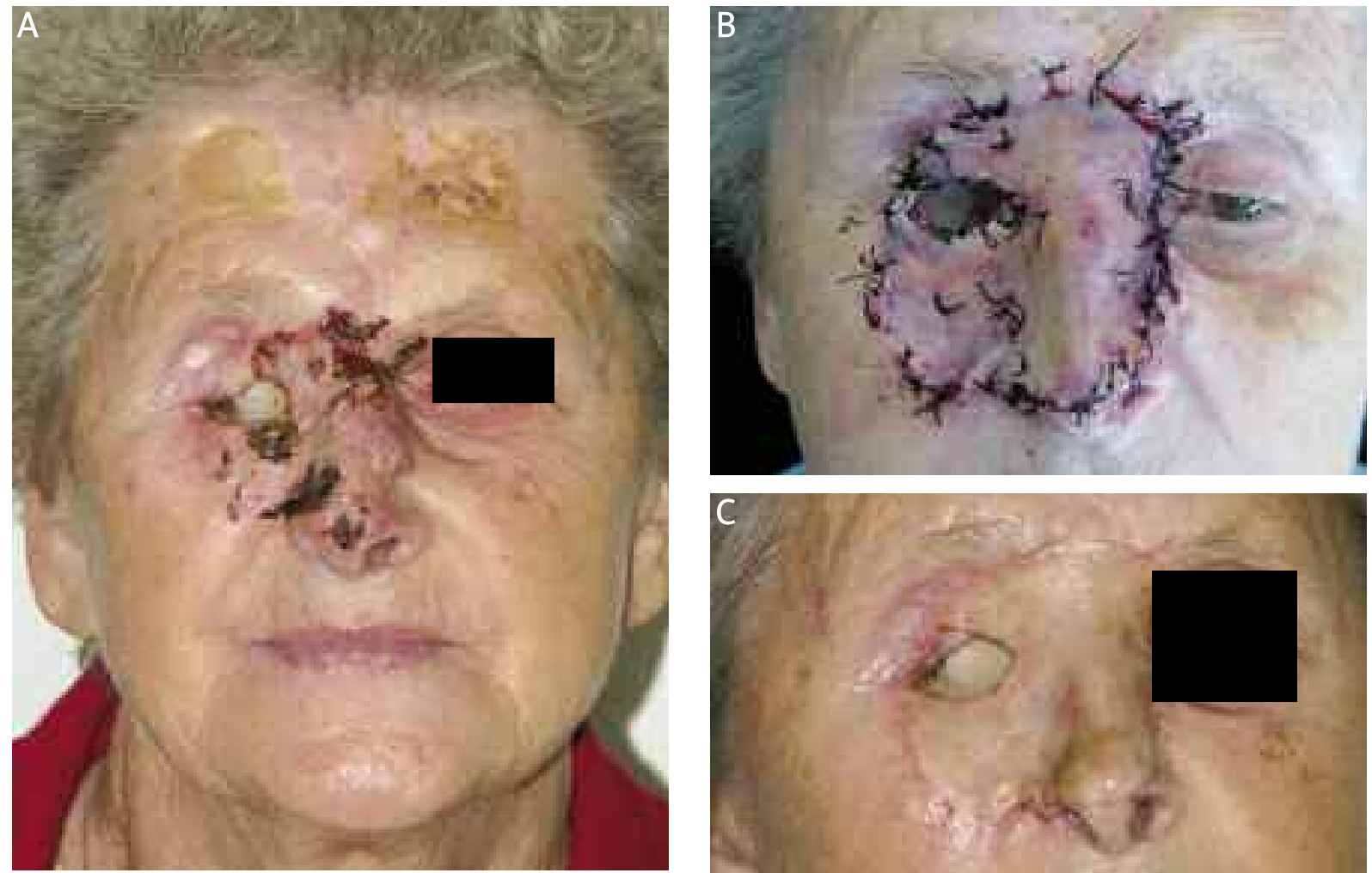

Figure 1. Patient 67 years old. Facial skin tumor in the central area, ulcerating, measuring $5 \mathrm{~cm} \times 6 \mathrm{~cm}$. Histopathological diagnosis: BCC, infiltrating the subcutaneous tissue. Under local anesthesia excision with a margin of $0.5 \mathrm{~cm}$ was performed. The defect was covered with full-thickness skin graft taken from the anterio-medial part of the right shoulder
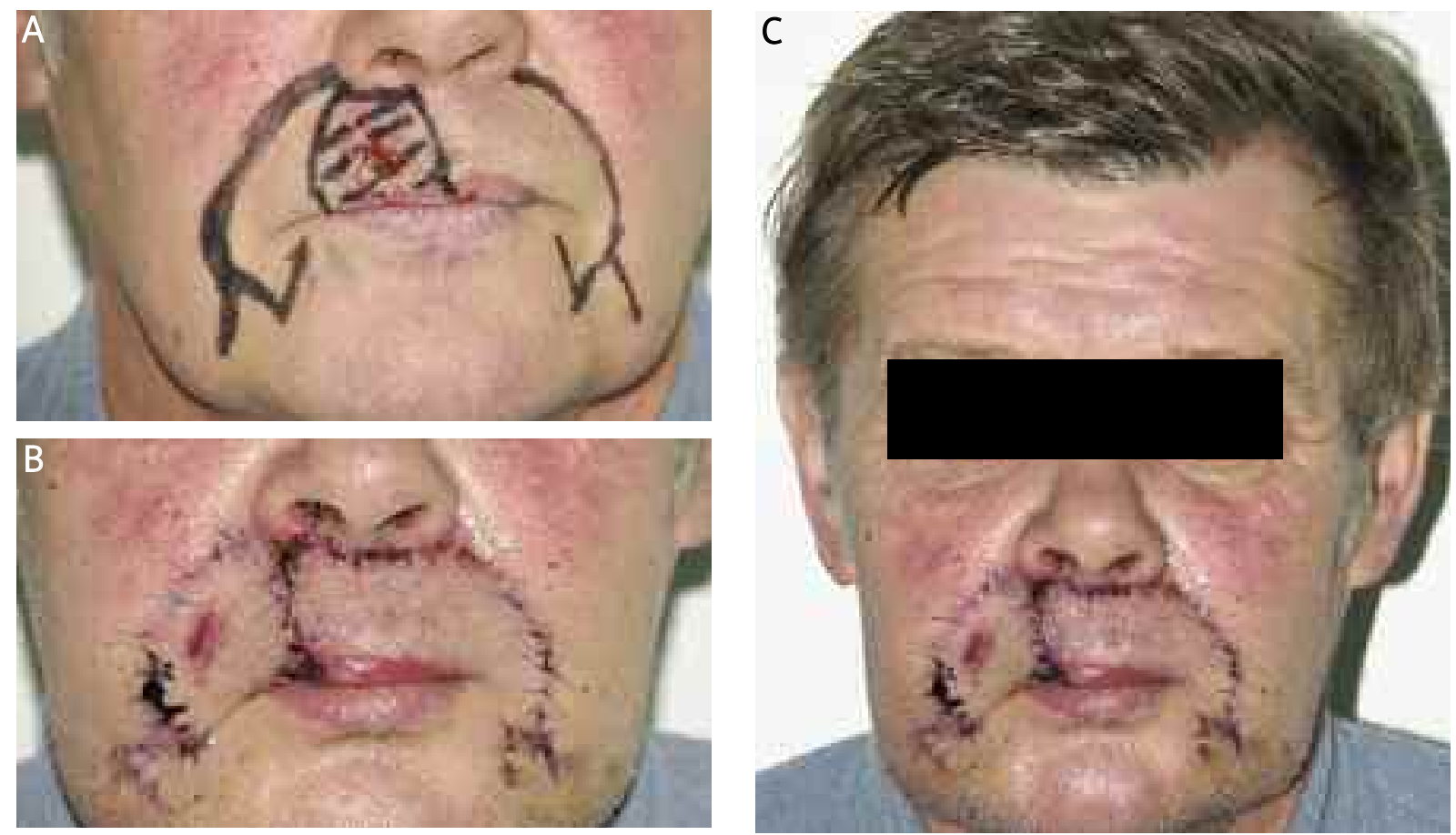

Figure 2. Patient 55 years old. A tumor with ulceration of the upper lip with a diameter of $2 \mathrm{~cm}$. Histopathological diagnosis: BCC. The tumor was excised under local anesthesia and surgery using the way of Gilles was performed (excision of orbicularis oris muscle with transposition of tissues upwards and medially). Additionally, a Z-plasty was performed 

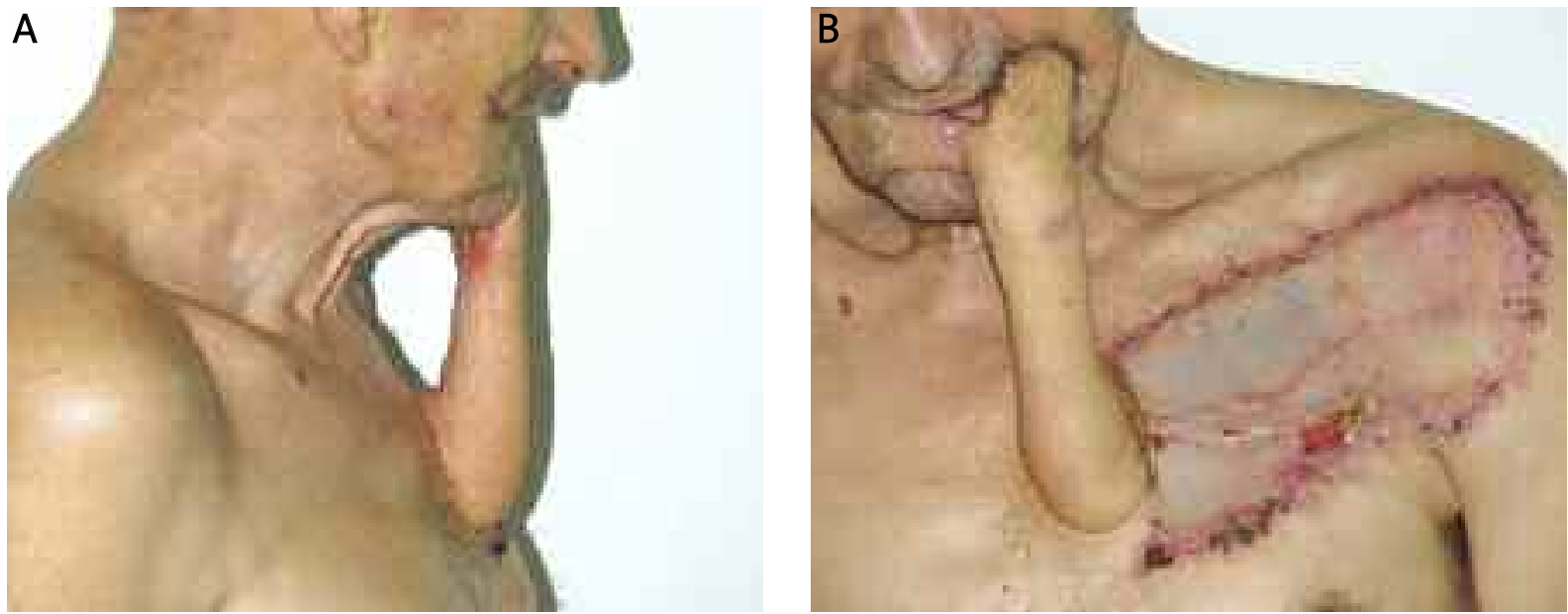

Figure 3. Patient 63 years old. A tumor of the left lower lip and cheek. Histopathological diagnosis: SCC keratodes G2. Excision and flap plasty using Bakamjan flap was performed. Secondary loss was covered with split- thickness skin graft taken from the thigh
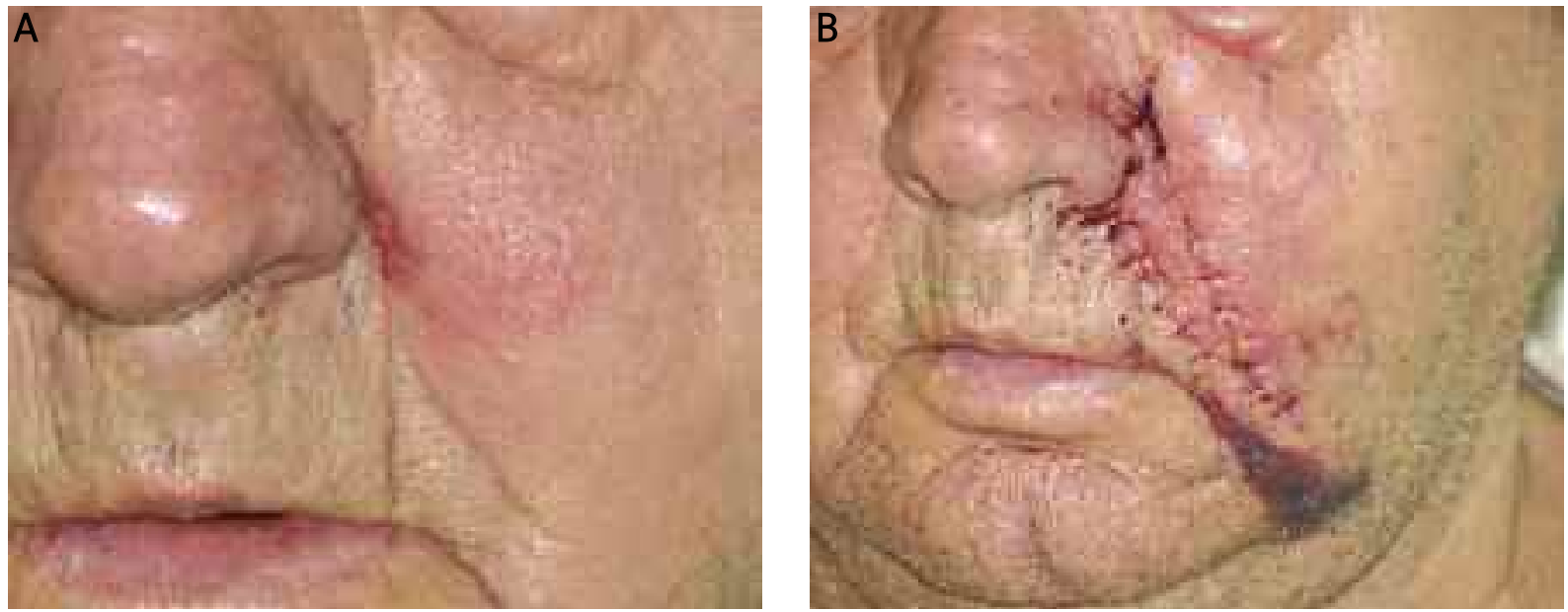

Figure 4. Patient 78 years old. Tumor around the naso-labial fold on the left side with dimensions of $1 \mathrm{~cm} \times 0.5 \mathrm{~cm}$. Histopathological diagnosis: BCC. Excision was performed with V-Y plasty
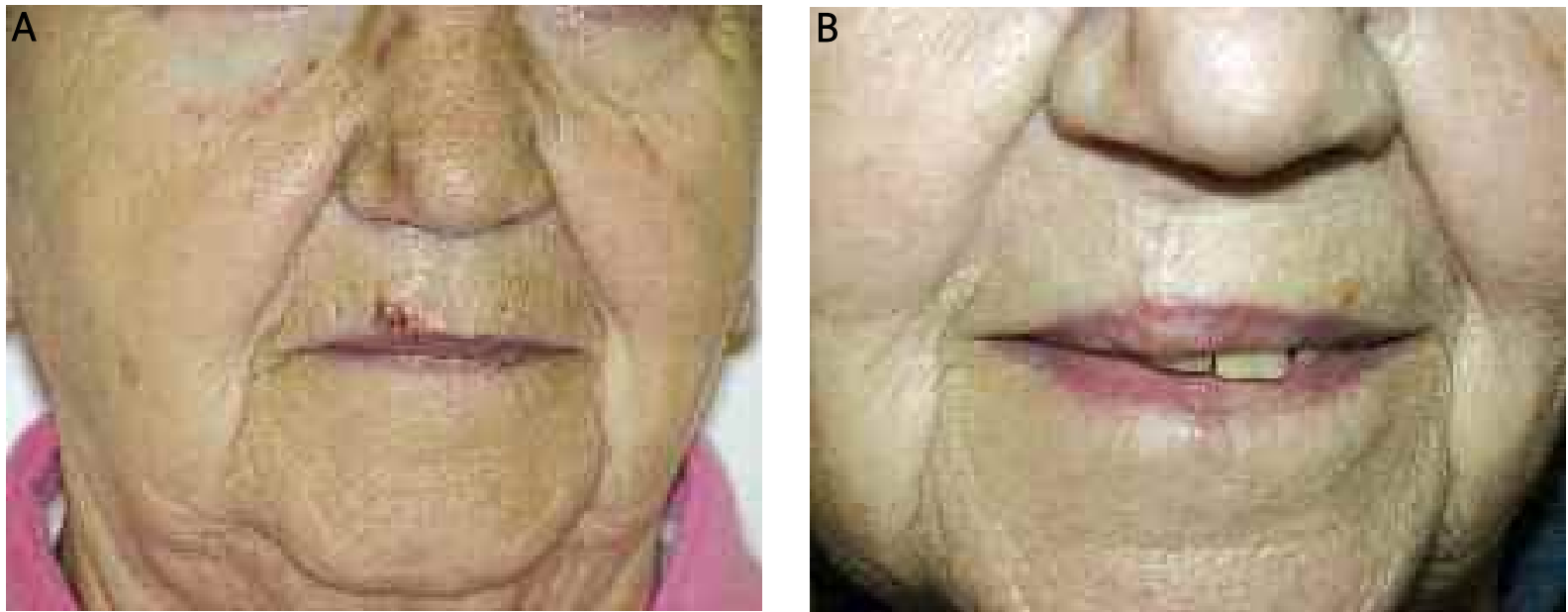

Figure 5. Patient 82 years old. Tumor of the upper lip, tumor's size $1 \mathrm{~cm} \times 2 \mathrm{~cm}$. Histopathological diagnosis: BCC exulcerans. Wedge resection of the tumor was performed 

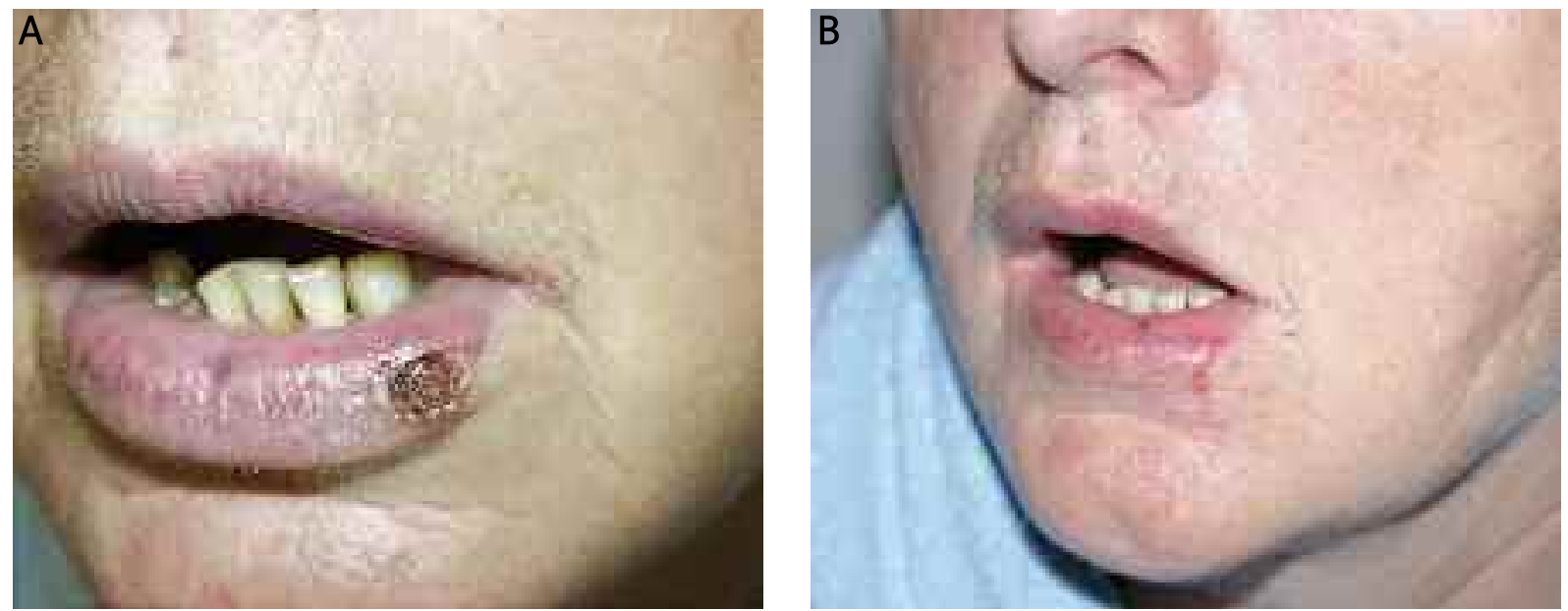

Figure 6. Patient 53 years old. Tumor of vermillion of the lower lip. Histopathological diagnosis: SCC. Wedge resection with a wide margin was performed

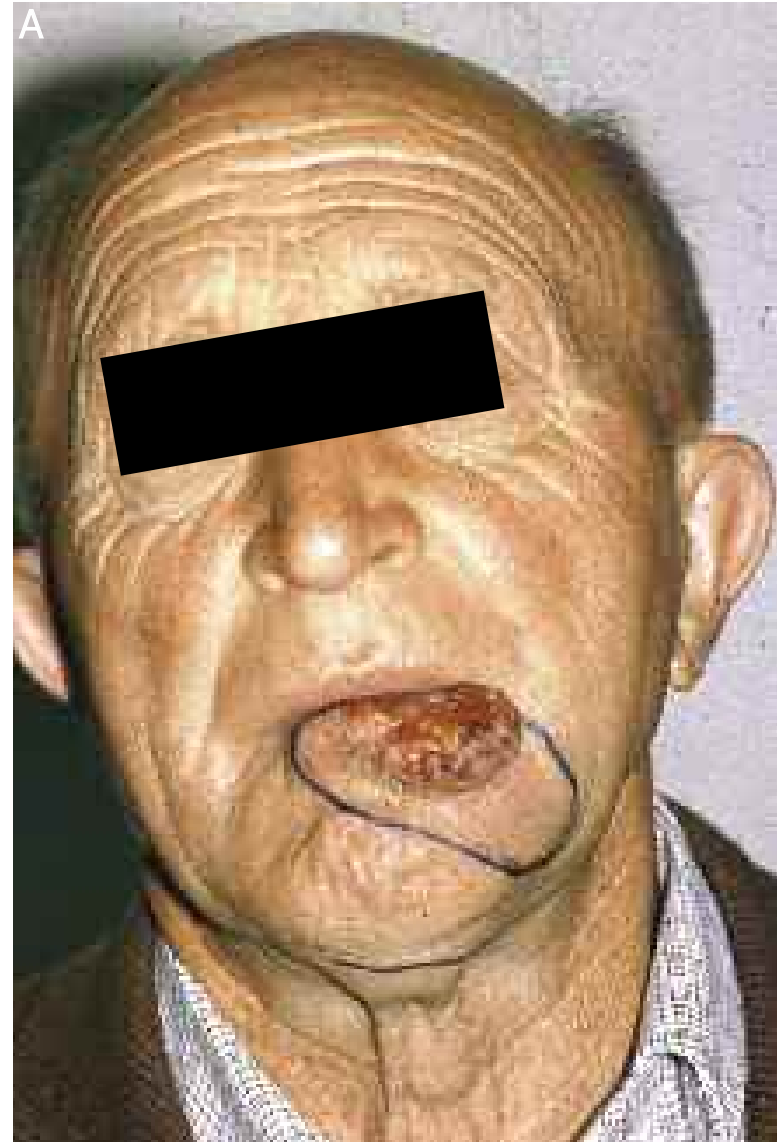

Figure 7. Patient 71 years old. Tumor of the lower lip. Histopathological diagnosis: SCC. The defect was covered with flaps from the neighborhood
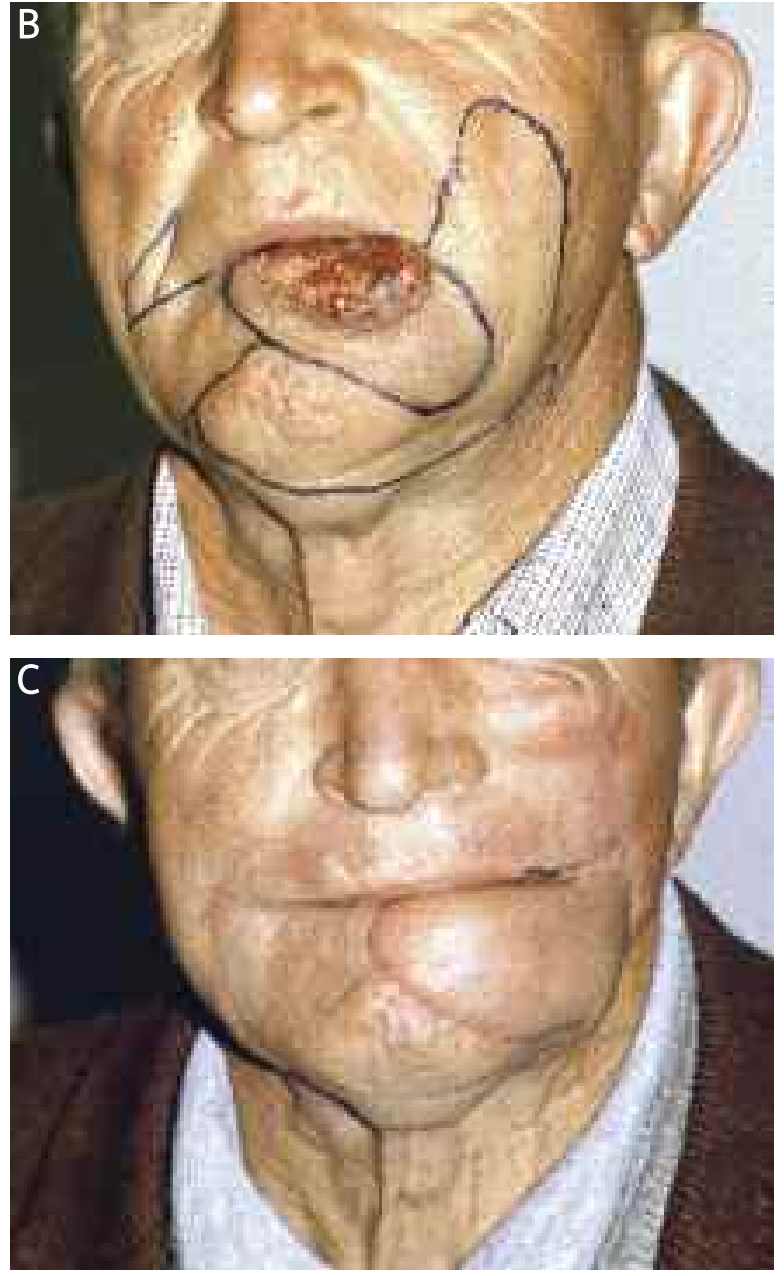

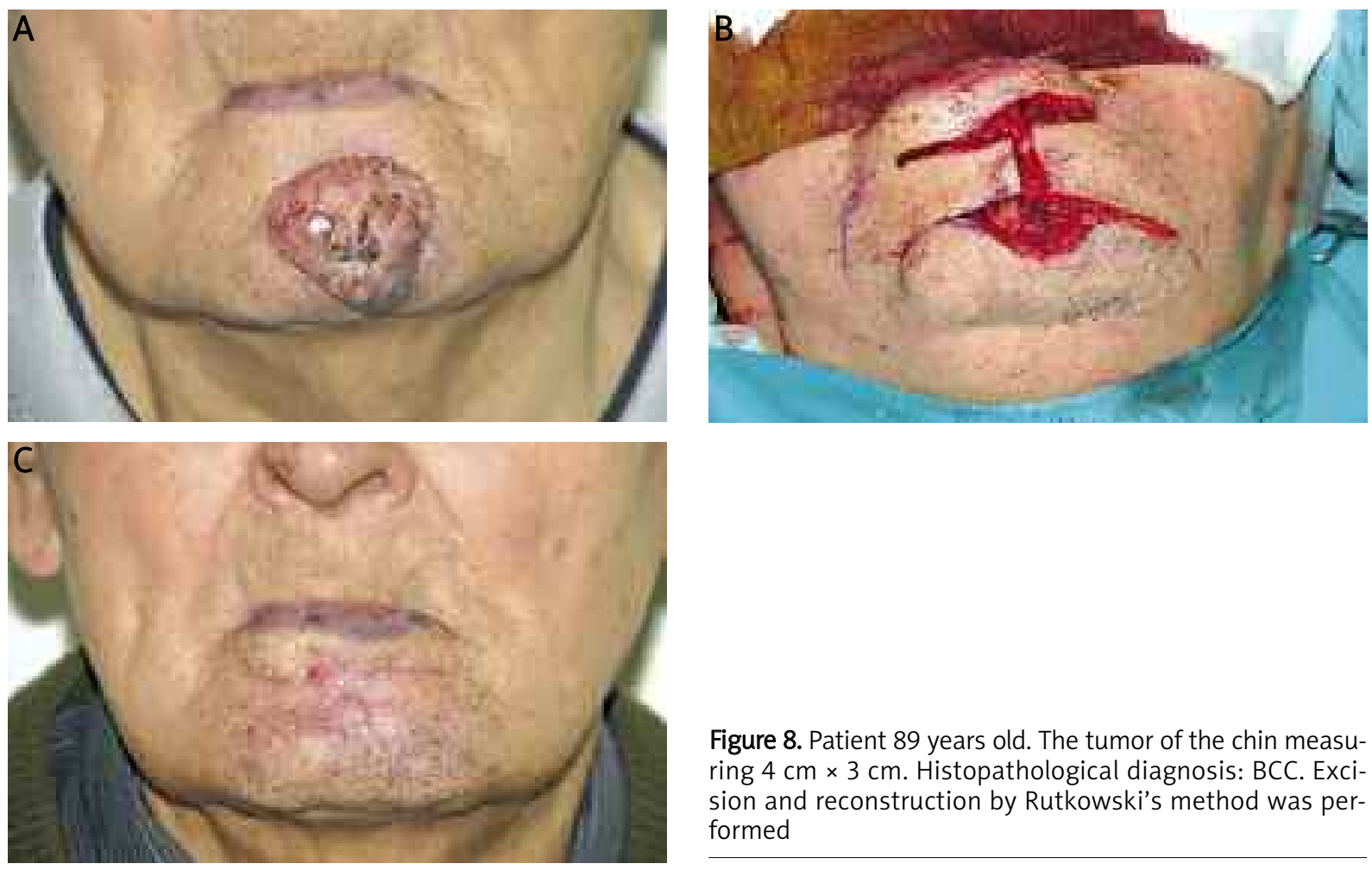

Figure 8. Patient 89 years old. The tumor of the chin measuring $4 \mathrm{~cm} \times 3 \mathrm{~cm}$. Histopathological diagnosis: BCC. Excision and reconstruction by Rutkowski's method was performed
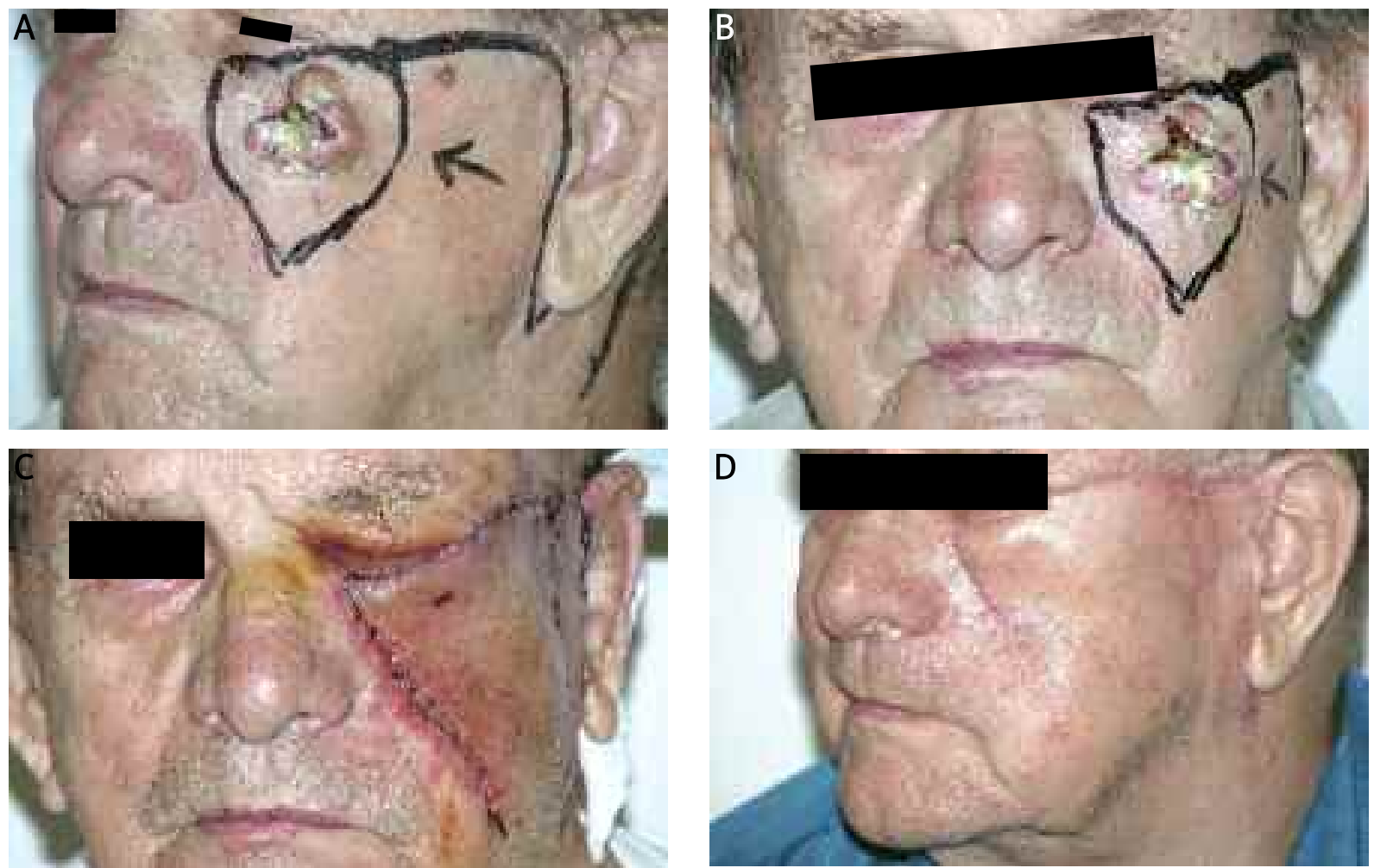

Figure 9. Patient 83 years old. The tumor in the left zygomatic area with a diameter of $4 \mathrm{~cm} \times 5 \mathrm{~cm}$, dilapidated, festering, associated with the base. Histopathological diagnosis: BCC. The tumor was excised under local anesthesia. Plasty was done using buccal and retroauricular lobe 

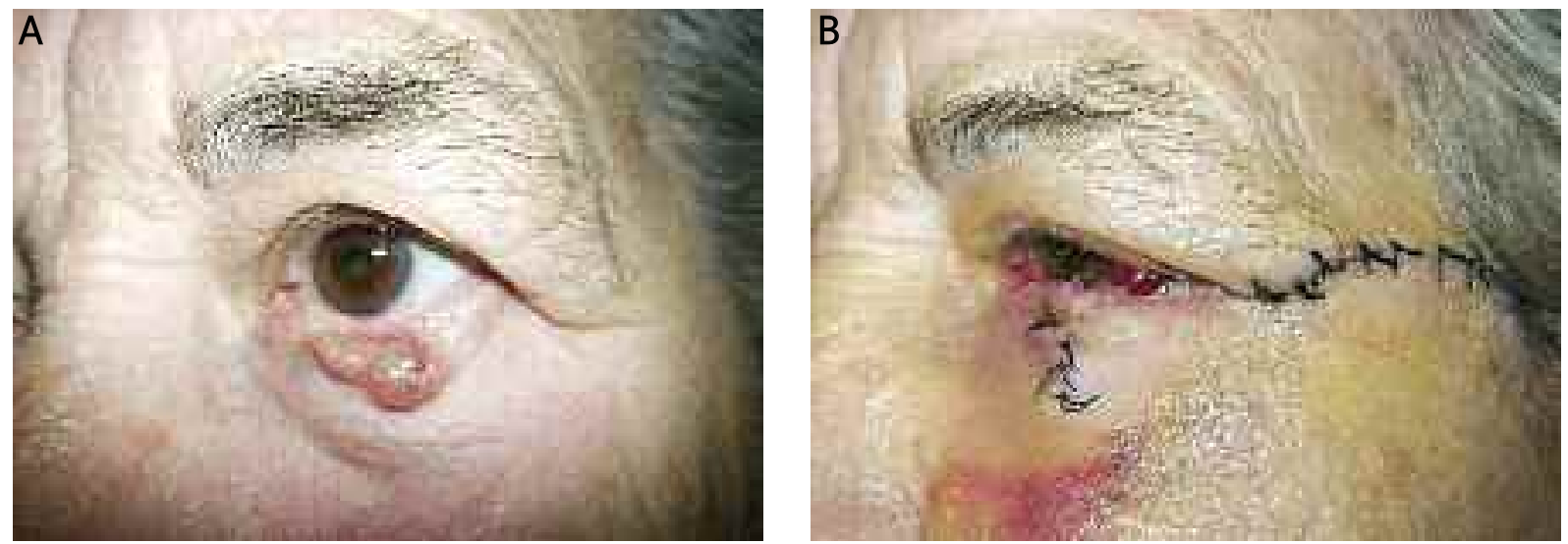

Figure 10. Patient 78 years old. Tumor of the lower eyelid of the left eye. Histopathological diagnosis: BCC. Excision with the buccal flap plasty was performed
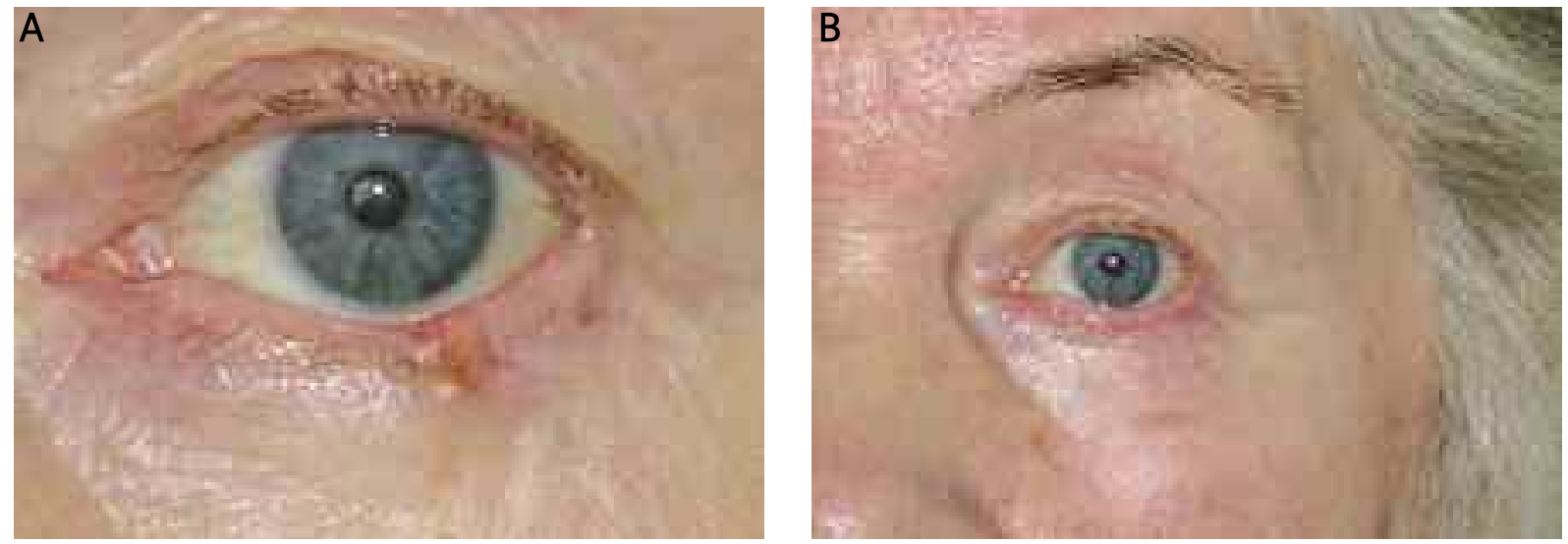

Figure 11. Patient 69 years old. Tumor of the lower eyelid of the left eye with a diameter $4 \mathrm{~mm}$. Histopathological diagnosis: carcinoma adenosquamosum cutis//adenosquamous carcinoma. Wedge resection of the tumor was performed
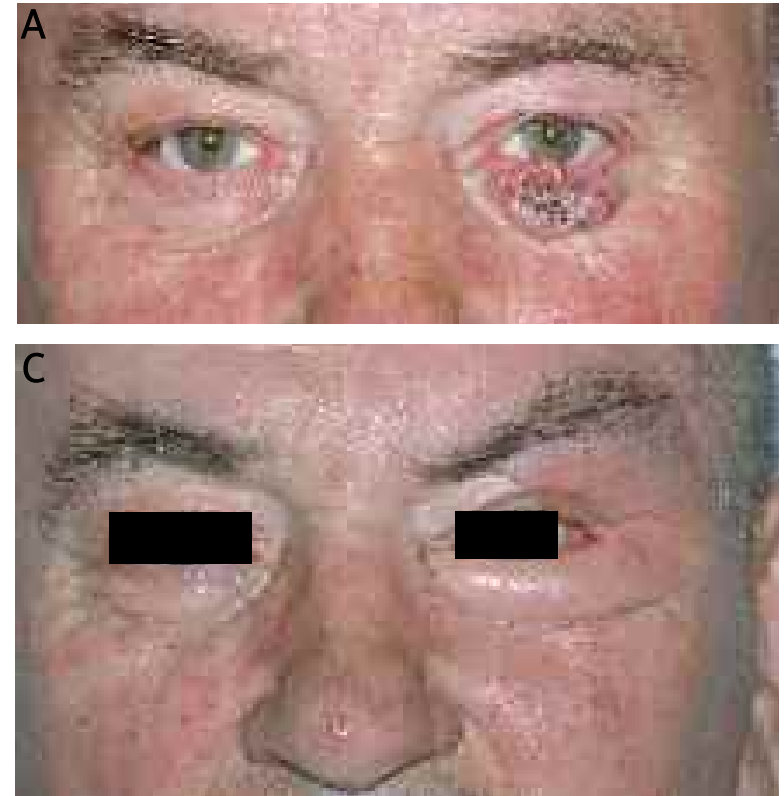

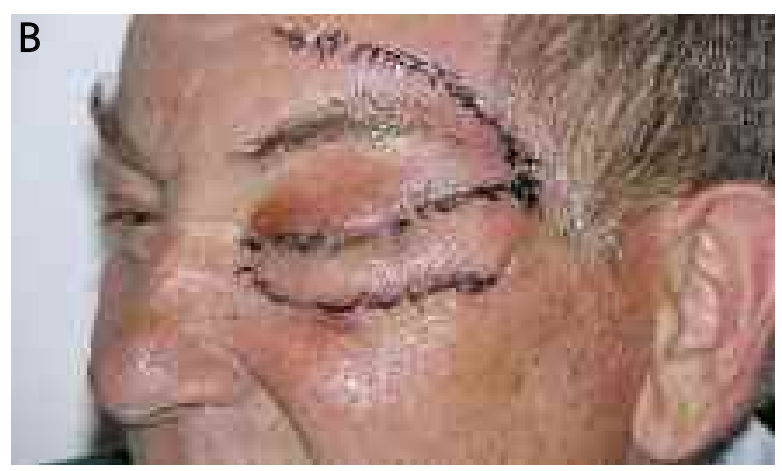

Figure 12. Patient 65 years old. Tumor of the lower eyelid of the left eye. Histopathological diagnosis: BCC. Frickie's flap reconstruction of the forehead was performed 

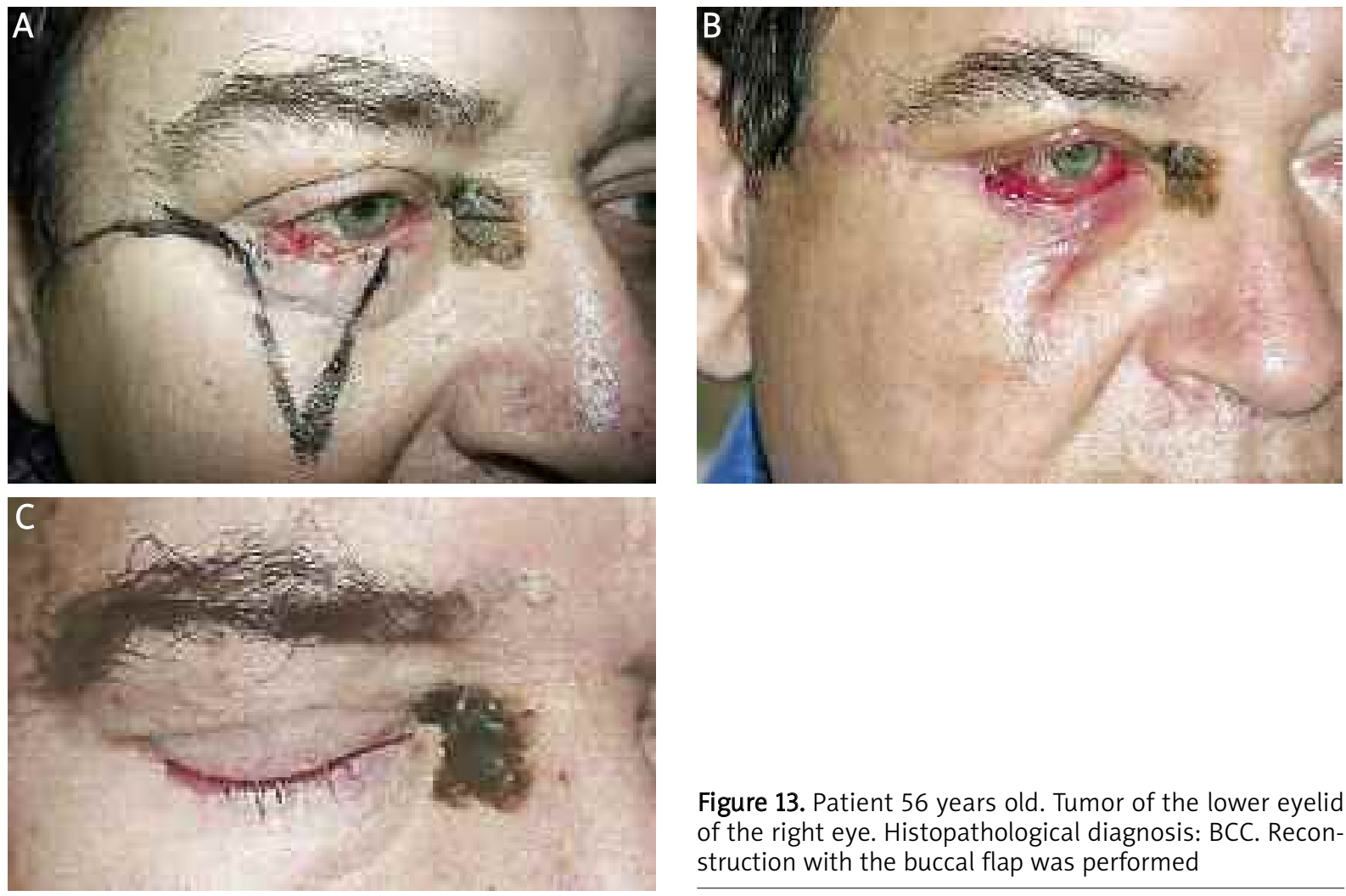

Figure 13. Patient 56 years old. Tumor of the lower eyelid of the right eye. Histopathological diagnosis: BCC. Reconstruction with the buccal flap was performed
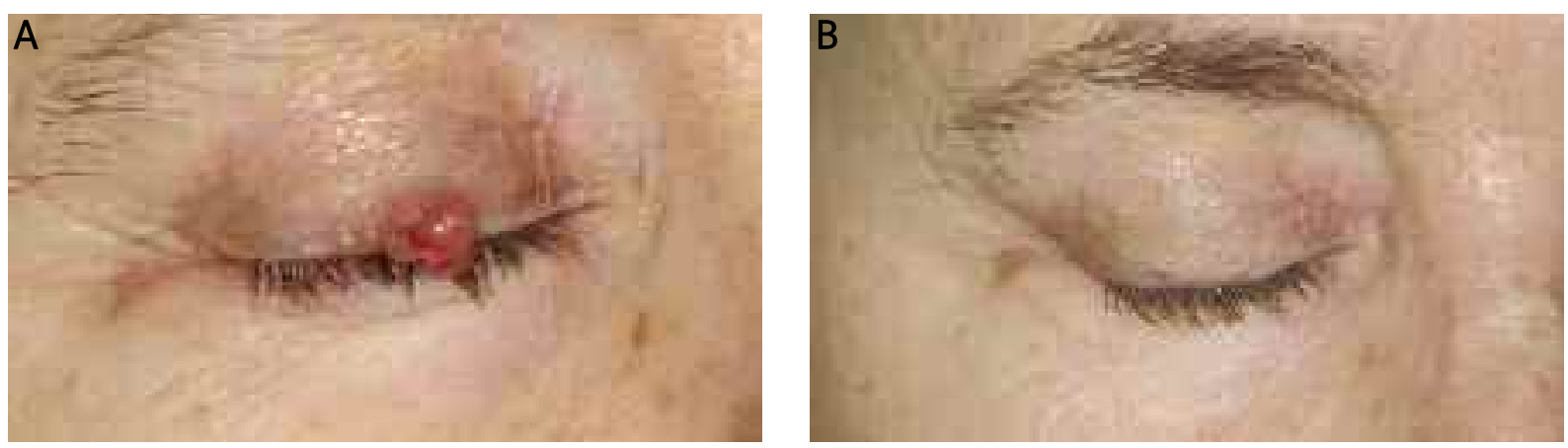

Figure 14. Patient 63 years old. Tumor of the upper eyelid of the right eye, $0.4 \mathrm{~cm}$ in diameter. Histopathological diagnosis: BCC. Wedge excision was performed
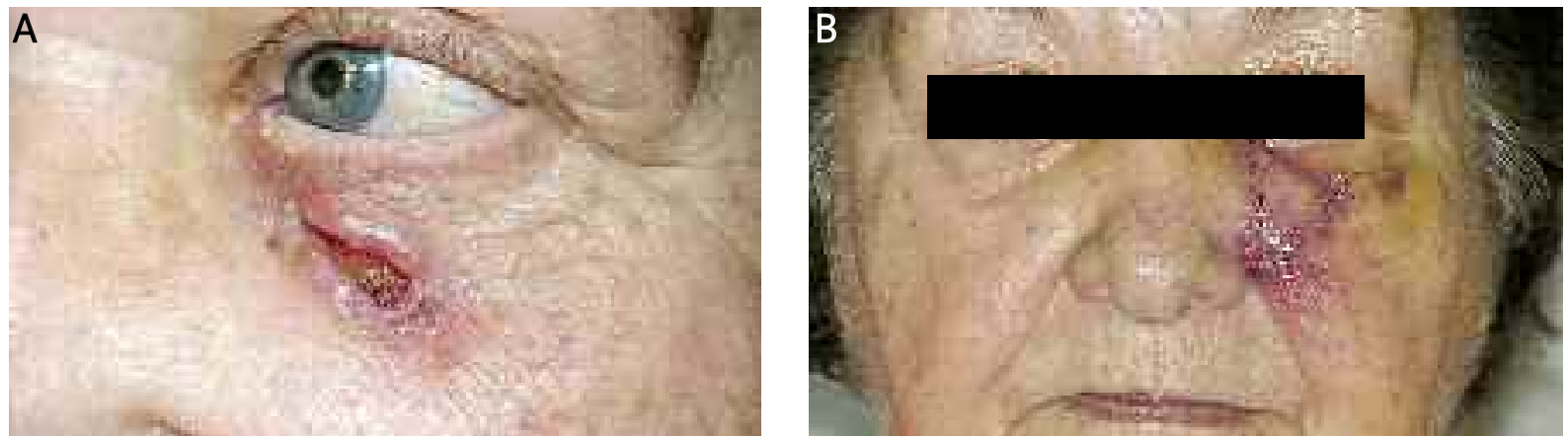

Figure 15. Patient 81 years old. Tumor of the eyelid of the left eye. Histopathological diagnosis: BCC. Plasty using Baron's flap (subcutaneous stalk) was performed 

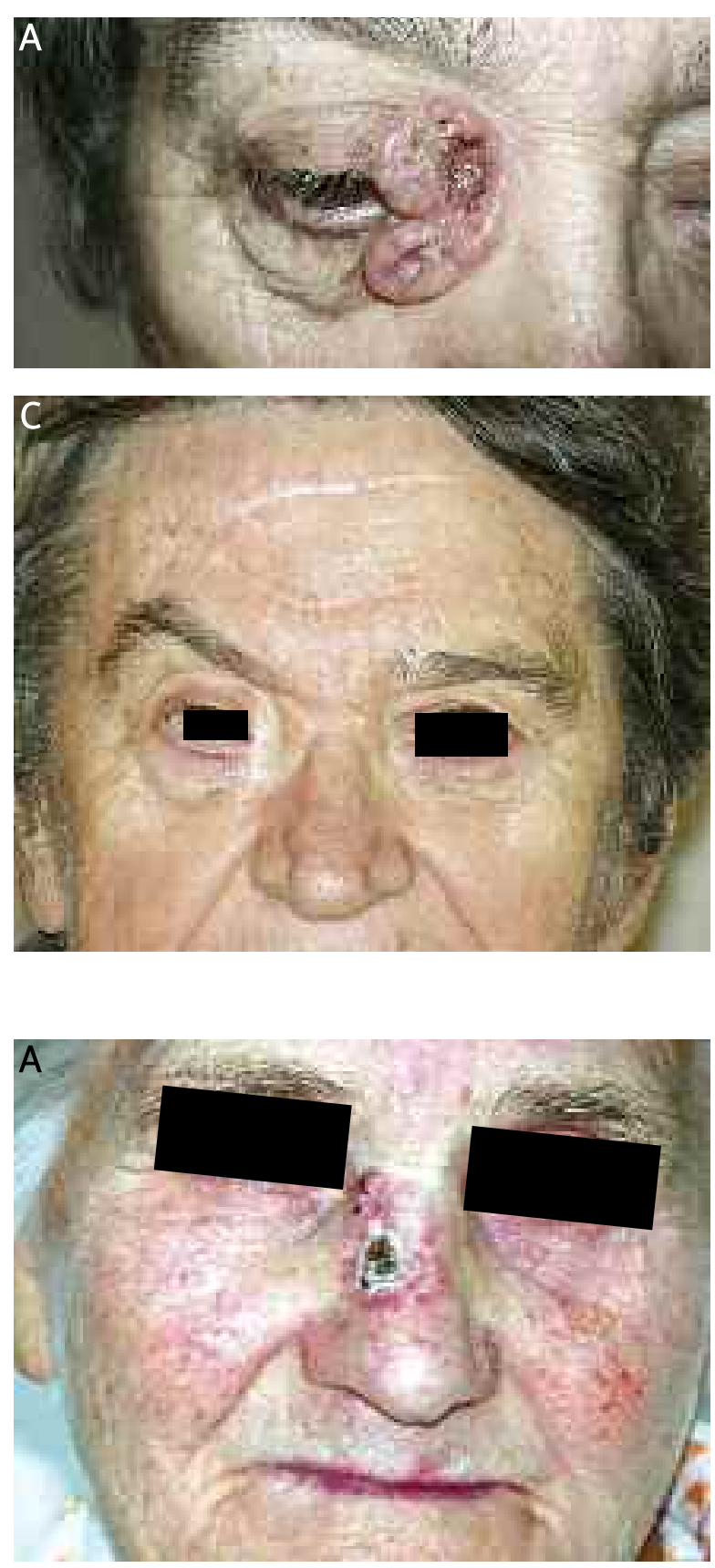

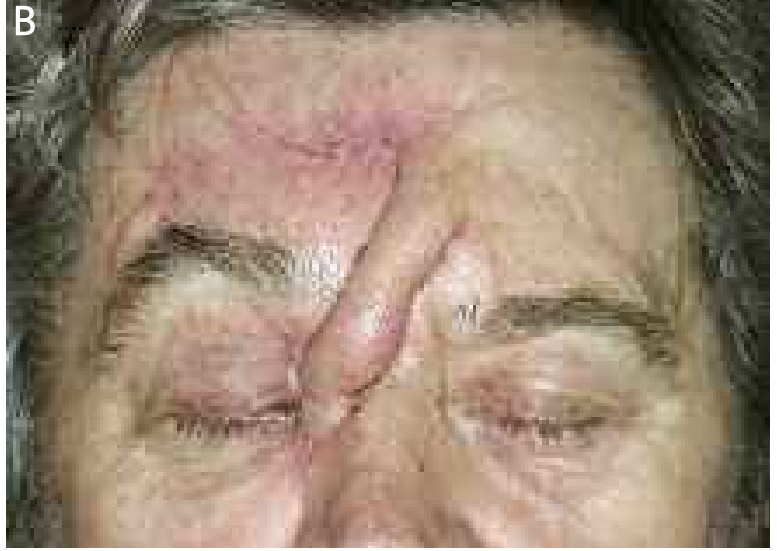

Figure 16. Patient 74 years old. Tumor of the medial angle of the right eye. Histopathological diagnosis: BCC. The defect was covered with a pediculated flap from the forehead

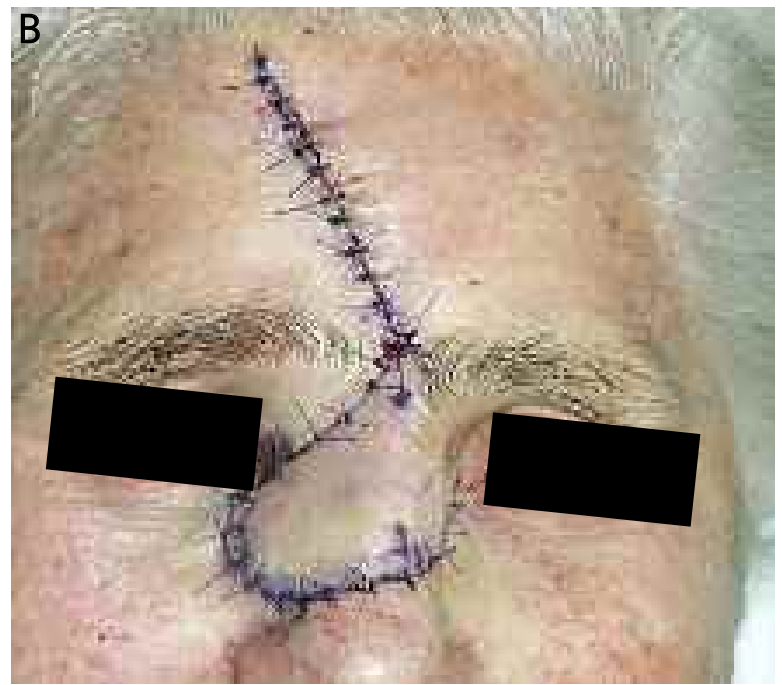

Figure 17. Patient 85 years old. The nasal tumor measuring $5 \mathrm{~cm} \times 2 \mathrm{~cm}$, ulcerated. Histopathological diagnosis: BCC. Excision was performed and a flap from glabella was used 

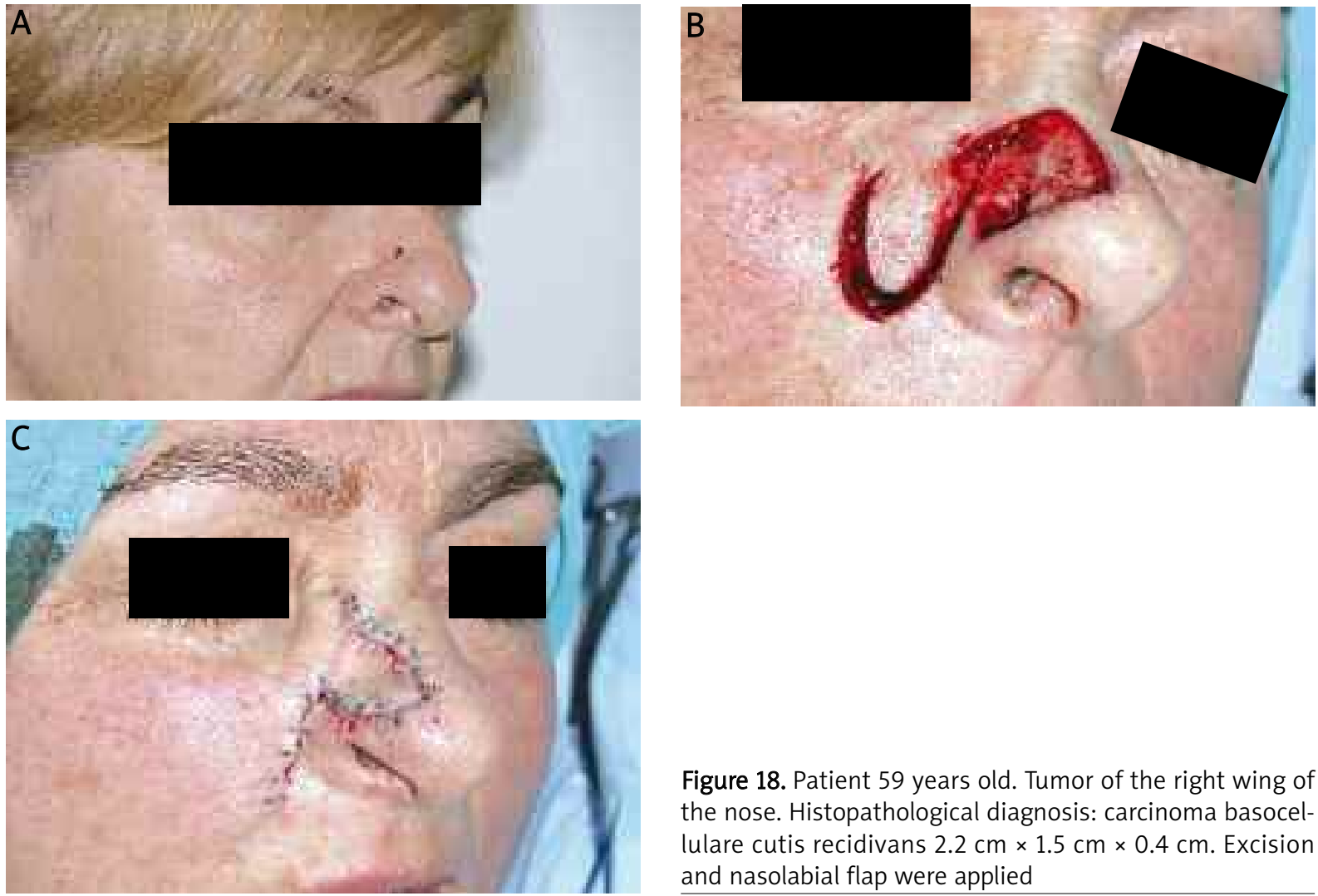

Figure 18. Patient 59 years old. Tumor of the right wing of the nose. Histopathological diagnosis: carcinoma basocellulare cutis recidivans $2.2 \mathrm{~cm} \times 1.5 \mathrm{~cm} \times 0.4 \mathrm{~cm}$. Excision and nasolabial flap were applied
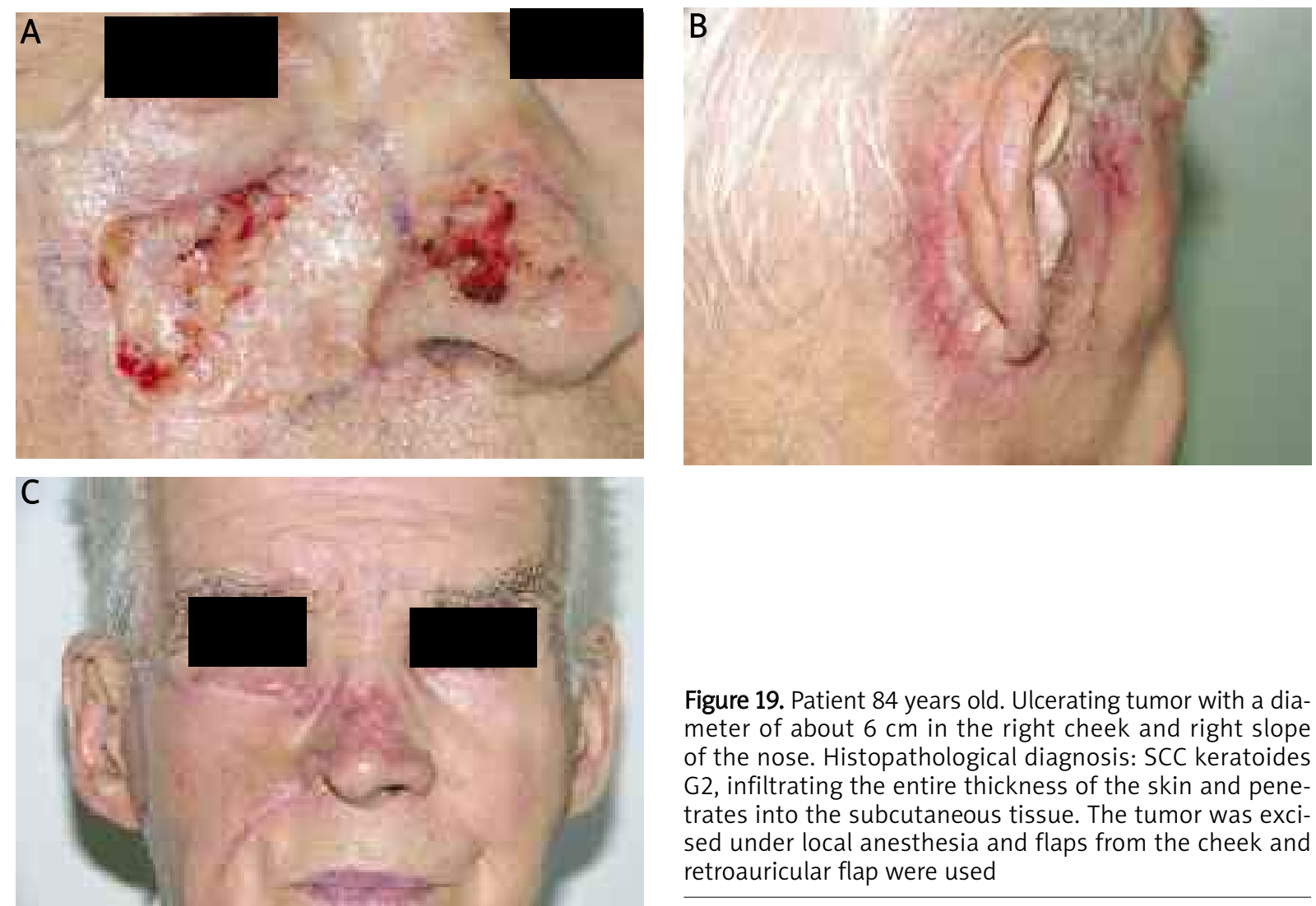

Figure 19. Patient 84 years old. Ulcerating tumor with a diameter of about $6 \mathrm{~cm}$ in the right cheek and right slope of the nose. Histopathological diagnosis: SCC keratoides G2, infiltrating the entire thickness of the skin and penetrates into the subcutaneous tissue. The tumor was excised under local anesthesia and flaps from the cheek and retroauricular flap were used 

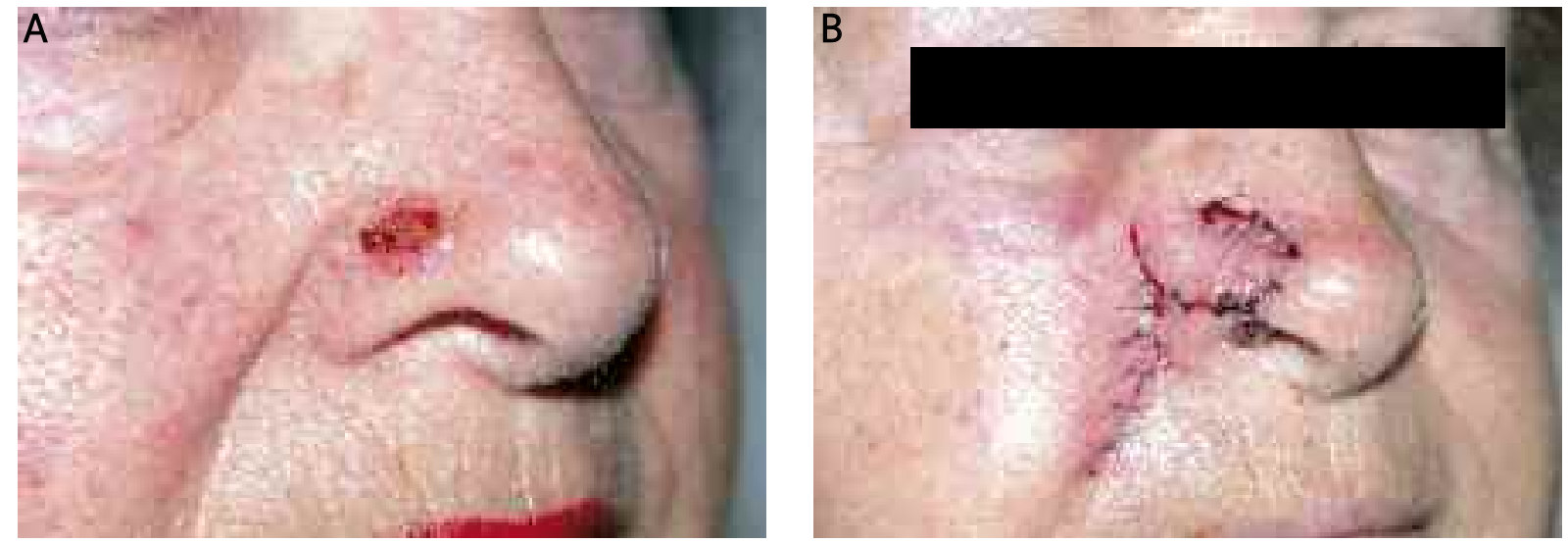

Figure 20. Patient 75 years old. Ulcerated nodule of the right wing of the nose with a diameter of $5 \mathrm{~mm}$. Histopathological diagnosis: BCC. Excision with a nasolabial fold flap was performed
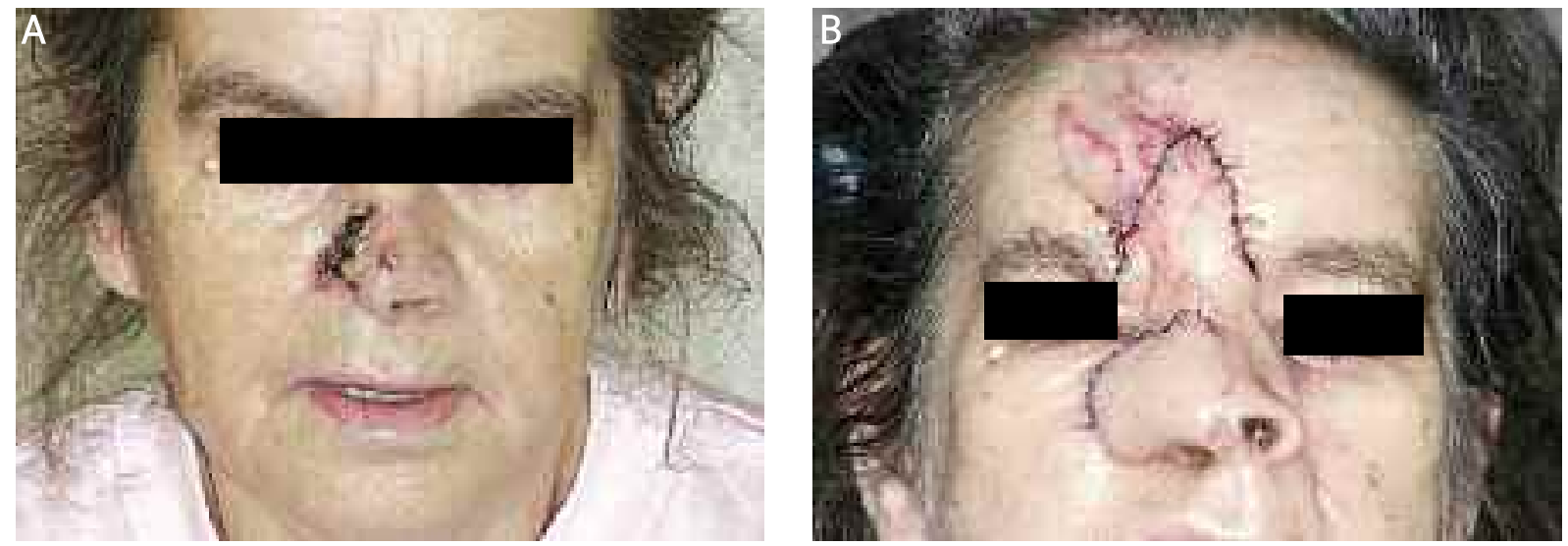

Figure 21. Patient 69 years old. Tumor of the right wing of the nose. Histopathological diagnosis: SCC. Excision and a forehead flap was used
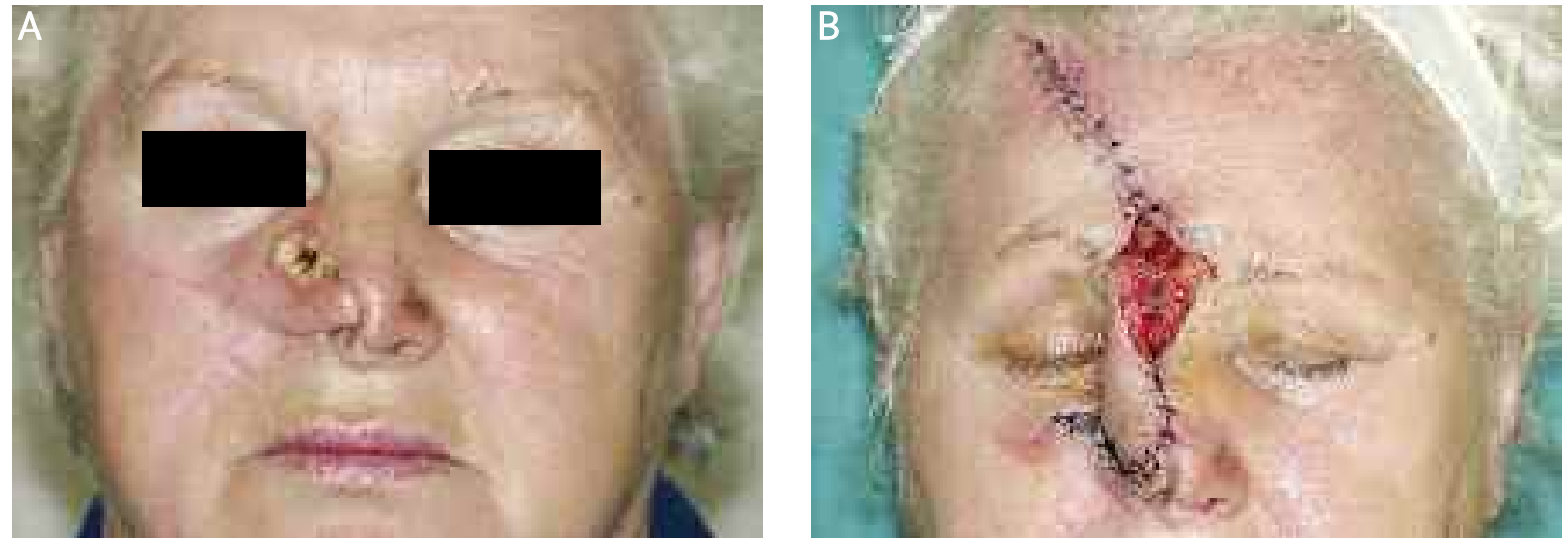

Figure 22. Patient 63 years old. Tumor of the right wing of the nose. Histopathological diagnosis: SCC keratodes G2. Excision and a forehead flap was used 

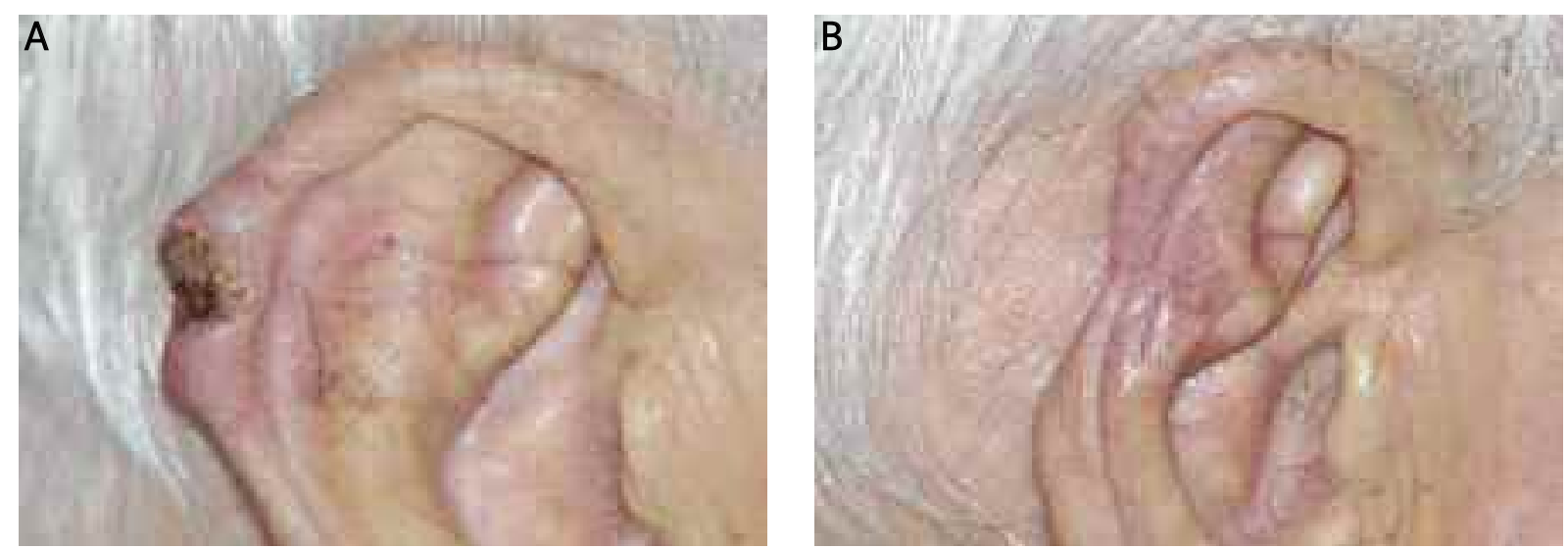

Figure 23. Patient 82 years old. Tumor of the right auricle with a diameter of about $3 \mathrm{~cm}$. Histopathological diagnosis: SCC G2. Wedge resection of the tumor was performed
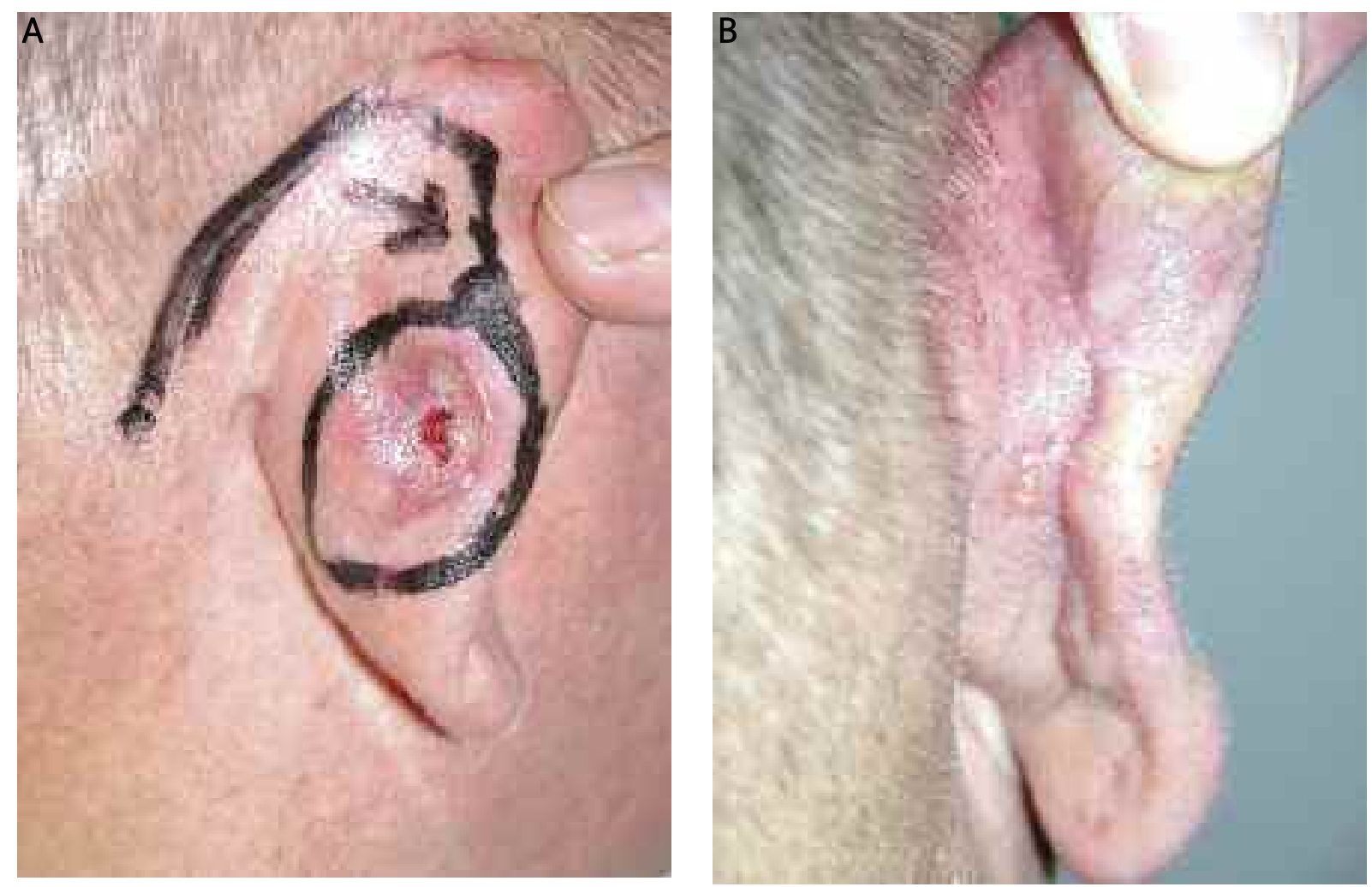

Figure 24. Patient 66 years old. Tumor of the right auricle. Histopathological diagnosis: BCC. The defect was covered with a rotation flap

the nose can be prefabricated (on the forearm) and transposed by microvascular techniques (Figures 17-22).

5. Earlobe

Small defects of the auricle are supplied with wedge excision and primary closure. Local flaps from the neighborhood or retroauricular flap can be used (Figures 23-24).

\section{Conclusions}

Despite enormous progress in medical science, surgery remains the method of choice in treating facial cancers. Only the primary cut and the suitable technique of plastic surgery, selected individually for each patient provide satisfactory results. 


\section{References}

1. Miller S. Etiology and pathogenesis of basal cell carcinoma. Clinics in Dermatology 1995; 13: 527-36.

2. Parkin DM, Pisani P, Ferley J. Global cancer statistics CA cancer J Clin 1999; 49: 33-64.

3. Adinarayan M, Krishnamurthy S. Clinicopathological evaluation of nonmelanoma skin cancer. Indian J Dermatol 2011; 56: 670-2.

4. Andrade P, Brites M, Vieira R, et al. Epidemiology of basal cell carcinomas and squamous cell carcinoma in Department of Dermatology - a 5 year reviev. An Bras Dermatol 2012; 87: 212-9.

5. Vitaliano PP, Urbach F. The relative importance of risk factors in nonmelanoma carcinoma. Arch Dermatol 1980; 116: 454-6.

6. Kordek, et al. Onkologia Podręcznik dla studentów i lekarzy. Via Medica, Gdańsk 2007; 41: 271-9.

7. Pearl DK, Scott EL. The anatomical distribution of skin cancers. Int J Epidemiol 1986; 15: 502-6.

8. Brash DE, Ziegler A, Jonason AS, et al. Sunlight and sunburn in human skin cancer: p53, apoptosis and tumor promotion. Invest Dermatol Symp Proc 1996; 1: 136-42.

9. Stern RS, Lange R. Non-melanoma skin cancer occurring in patients treated with PUVA five to ten years after first treatment. J Invest Dermatol 1988; 91: 120-4.

10. Ron E, Modan B, Preston D. Radiation-induced skin carcinomatosis of the head and neck. Radiation Res 1991; 125: 318.

11. Birkeland SA, Storm HH, Lamm LU, et al. Cancer risk after renal transplantation in the Nordic countries, 1964-1986. Int J Cancer 1995; 60: 183-9.

12. Franceschi S, Dal Maso L, Arniani S, et al. Risk of cancer other than Kaposi's sarcoma and non- Hodgkin's lymphoma in persons with AIDS registry linkage study. Br J Cancer 1998; 78: 966-70.

13. Hahn SB, Kim DJ, Jeon CH. Clinical study of Marjolin's ulcer. Yonsei Med J 1990; 31: 234.

14. Yuspa SH. Cutaneous chemical carcinogenesis. J Am Acad Dermatol 1986; 15: 1031-44.

15. Glogau RG. Actinic keratoses - scientific evaluation and public health implications: the risk of progression to invasive disease. J Am Acad Dermatol 2000; 42: 23-4.

16. Stone N, Reed J, Mahood J, et al. Xeroderma pigmentosum, the role of photo testing. Br I Dermatol 2000; 143: 595-7.

17. Mc Kenna KE, Somerville JE, Walsh MY, et al. Basal cell carcinoma occurring in association with dermatofibroma. Dermatology $1993 ; 187:$ : $54-7$.

18. Jones EW, Heyl T. Naevus sebaceous: a report of 140 cases with special regard to the development secondary malignant tumors. Br J Dermatol 1970; 82: 99-117.

19. Wyrzykowska N, Więckowicz-Rosińska A, Bartoszak L, et al. Bowen's disease and basal cell carcinoma in a renal transplant recipient - case report. Postep Derm Alergol 2011; 28: 138-41.

20. Graham JH, Helwig EB. Bowen's disease and its relationship to systemic cancer. Arch Dermatol 1959; 80: 133-59.

21. Lever WF. Tumors and cysts of the epidermis. In: Histopathology of the skin. Lever WF, Schaumberg-Lever S (eds). $7^{\text {th }}$ ed. JB Lippincott, Philadelphia 1990; 546.

22. Konigova R, Rychterova V. Majrolin's ulcer. Acta Chir Plast 2000; 42: 91.

23. Takata M. Nevoid basal cell carcinoma syndrome. Nippon Rinsho 2000; 58: 1376-80.

24. Lacour JP. Carcinogenesis of basal cell carcinomas: genetics and molecular mechanisms. Br J Dermatol 2002; 146 (Suppl 61): 17-9.

25. Gherardini G, Bhatia N, Stal S. Congenital syndromes associated with nonmelanoma skin cancers. Clin Plast Surg 1997; 24: 655 .
26. Wong CMS, Strange RC, Lear JT. Clinical review. Basal cell carcinoma. BMJ 2003; 327: 794-8.

27. Scrivener Y, Grosshans E, Cribier B. Variations of basal cell carcinomas according to gender, age, location, and histopathological subtype. Br J Dermatol 2002; 147: 41-7.

28. Telfer N, Colver G, Morton C. Guidelines fort he menagement of basal cell carcinoma. Br J Dermatology 2008; 159: 35-48.

29. Sartore L, Lancerotto L, Salmaso M, et al. Facial basal cell carcinoma: analysis of recurrence and follow up strategies. Oncol Rep 2011; 26: 1423-9.

30. Silverman MK, Kopf AW, Bart RS. Recurrence rates of treated basal cell carcinomas: surgical excision. J Dermatol Surg Oncol 1992; 18: 471.

31. Rove DE, Carrol RJ, Day CL Jr. Prognostic factors for local recurrence metastasis and survival rates in squamous cell carcinoma of the skin, ear and lip. Implications for treatment modality selection. J Am Acad Dermatol 1992; 266: 976-90.

32. Broders AC. Squamous-cell epithelioma oft he skin. Ann Surg 1921; 73: 141.

33. Mathes SJ. Plastic surgery. Vol. 5. Saunders Elsevier, Philadelphia 2006.

34. Rank BK, Wakefield AR. Surgery of basal cell carcinoma. Br J Surg 1958; 45: 531-47.

35. Lukic D, Karabeg R, Jeremic $P$, et al. The results of treatment of basocdellular carcinomas of the head skin. Med Arh 2012; 66: 169-72.

36. Anthony ML Surgical treatment of nonmelanoma skin cancers. AORN J 2000; 71: 552-4.

37. Geisse JK. Comparison of treatment modalities for squamous cell carcinoma. Clin Dermatol 1995; 13: 621-6.

38. Salasche SJ. Status of curettage ad desiccation in the treatment of rimary basal cell carcinoma. J Am Acad Dermatol 1984; 10: 285-7.

39. Lowrence CM. Moh's micrographic surgery for basal cell carcinoma. Clin Exp Dermatol 1999; 24: 130-3.

40. Veronese F, Farinelli P, Zavatarro E, et al. Basal cell carcinoma oft he head region: therapeutic results of 350 lesions treated with Mohs micrographic surgery. J Eur Dermatol Venerol 2012; 26: 838-43.

41. Goette DK. Topical chemotherapy with 5-fluorouracil. J Am Acad Dermatol 1981; 6: 633-49.

42. Gargiulo M, Papa A, Capasso P, et al. Electrochemotherapy for non-melanoma head and neck cancers: clinical outcomes in 25 patients. Ann Surg 2012; 255: 1158-64.

43. Chimenti S, Peris K, Di Cristofaro S, et al. Use of recombinant interferon alfa-2b in the treatment of basal cell carcinoma. Dermatology 1995; 190: $214-7$.

44. Nag S, Caro ER, Demanes JD, et al. The American Brachytherapy Society recommendations for high dose rate brachytherapy for head and neck carcinoma. Int J Oncol Biol Phys 2001; 50: 1190-8.

45. Locke J, Karimpour S, Young G, et al. Radiotherapy for epithelial skin cancer. Int J Radiat Oncol Bio Phys 1990; 19: 235-42.

46. Kuflik EG, Gage A. The five-year cure rate achieved by cryosurgery for skin cancer. J Am Acad Dermatol 1991; 24: 1002-4.

47. Gaitanis G, Alexopoulos EC, Bassukas ID. Cryosurgery is more effective in the treatment of primary, non superficial basal cell carcinomas when applied during and not prior to five week imiquimod course: a randomized, prospective, open-label study. Eur J Dermatol 2012; 21: 952-8.

48. Flechter S, Skaria A, Nievergelt H, et al. Facial basal cell carcinomas recurring after photodynamic therapy: a retrospective analysis of histological subtypes. Dermatology 2012; 224: 346-51. 